University of Nebraska - Lincoln

DigitalCommons@University of Nebraska - Lincoln

Finance Department Faculty Publications

Finance Department

$5-2009$

\title{
Dividend Policy, Creditor Rights, and the Agency Costs of Debt
}

\author{
Paul Brockman \\ University of Missouri-Columbia, pab309@lehigh.edu \\ Emre Unlu \\ University of Nebraska-Lincoln, emre@unl.edu
}

Follow this and additional works at: https://digitalcommons.unl.edu/financefacpub

Part of the Finance and Financial Management Commons

Brockman, Paul and Unlu, Emre, "Dividend Policy, Creditor Rights, and the Agency Costs of Debt" (2009). Finance Department Faculty Publications. 13.

https://digitalcommons.unl.edu/financefacpub/13

This Article is brought to you for free and open access by the Finance Department at DigitalCommons@University of Nebraska - Lincoln. It has been accepted for inclusion in Finance Department Faculty Publications by an authorized administrator of DigitalCommons@University of Nebraska - Lincoln. 
Published in Journal of Financial Economics 92: (May 2009), pp. 276-299; doi: 10.1016/j.jfineco.2008.03.007

Copyright (C) 2009 Elsevier B.V. Used by permission. http://www.elsevier.com/locate/jfec

Submitted May 1, 2007; revised January 23, 2008; accepted March 23, 2008; published online February 4, 2009.

\title{
Dividend Policy, Creditor Rights, and the Agency Costs of Debt
}

\author{
Paul Brockman, University of Missouri-Columbia, Columbia, MO 65211, USA \\ Emre Unlu, University of Nebraska-Lincoln, Lincoln, NE 68588, USA \\ Corresponding author - P. Brockman, email brockmanp@missouri.edu
}

\begin{abstract}
We show that country-level creditor rights influence dividend policies around the world by establishing the balance of power between debt and equity claimants. Creditors demand and managers consent to a more restrictive payout policy as a substitute for weak creditor rights in an effort to minimize the firm's agency costs of debt. Using a sample of 120,507 firm-years from 52 countries, we find that both the probability and amount of dividend payouts are significantly lower in countries with poor creditor rights. A reduction in the creditor rights index from its highest value to its lowest value implies a $41 \%$ reduction in the probability of paying a dividend, and a $60 \%$ reduction in dividend payout ratios. These results are robust to numerous control variables, sample variations, model specifications, and alternative hypotheses. We also show that the agency costs of debt play a more decisive role in determining dividend policies than the previously documented agency costs of equity. Overall, our findings contribute to the growing literature arguing that creditors exert significant influence over corporate decision-making outside of bankruptcy.
\end{abstract}

Keywords: creditor rights, dividend policy, agency costs

\section{Introduction}

The principal-agent relation is the underlying source of many incentive problems in corporate finance. In broad terms, there are agency conflicts among various equity claimants (agency costs of equity), as well as between debt and equity claimants (agency costs of debt). La Porta, Lopez-de-Silanes, Shleifer, and Vishny (2000) analyze the extent to which minority shareholder rights influence dividend policies around the world through their impact on the agency costs of equity. They find that strong shareholder rights enable minority shareholders to obtain relatively high dividend payouts from reluctant managers and controlling shareholders. Minority shareholder rights influence dividend policies by establishing the country-level balance of power between inside and outside ownership interests. In this study, we posit that creditor rights influence dividend policies by establishing the country-level balance of power between debt and equity claimants. We argue that low dividend payouts serve as a substitute mechanism for weak creditor rights. Managers operating under weak creditor rights are more likely to consent to dividend restrictions through formal covenants and informal agreements in order to build reputation capital and reduce future financing costs. Our results confirm that the agency costs of debt play a significant role in determining dividend policies around the world.

La Porta, Lopez-de-Silanes, Shleifer, and Vishny (2000) propose two competing hypotheses for a causal relation between shareholder rights and dividend policy. The "out-

The authors would like to thank Matteo Arena, Marcia Cornett, Wallace Davidson, Richard DeFusco, Michael Dewally, Donna Dudney, Mark Eppli, Kathleen Farrell, Stephen Ferris, Geoffrey Friesen, John Geppert, William Hunter, Gordon Karels, George Kutner, Iqbal Mansur, Jim Musumeci, Sarah Peck, Anthony Pennington-Cross, Manferd Peterson, Mark Peterson, David Smith, Sterling Yan, Xiaoxin Wang, Christopher Wikle, Thomas Zorn, as well as seminar participants at Marquette University, Southern Illinois University-Carbondale, University of Nebraska-Lincoln, University of Missouri-Columbia, and Widener University. Financial support from the Office of Research at the University of Nebraska-Lincoln is gratefully acknowledged. 
come hypothesis" predicts that stronger rights will empower minority shareholders to obtain higher dividend payouts, and the "substitute hypothesis" predicts that weaker rights will lead to higher dividend payouts as managers use dividend payouts as a substitute for weak investor protection. They find that the outcome hypothesis explains the empirical linkages between the agency costs of equity, minority shareholder rights, and observed dividend payouts. In a parallel manner, we posit that the substitute hypothesis will explain the connections between the agency costs of debt, creditor rights, and observed dividend payouts. Restrictive dividend policies substitute for weak creditor rights; that is, weak (strong) creditor rights diminish (enhance) the manager's ability to pay out dividends, all else equal. ${ }^{1}$ In addition to confirming the agency costs of debt version of the substitute hypothesis, our results also show that the agency costs of debt play a more pervasive role in dividend policies around the world than the agency costs of equity.

There is considerable variation in creditor rights across countries with similar legal origins and shareholder rights. ${ }^{2}$ For example, the US, UK, Canada, and Australia are all common law countries that tend to rank towards the top of the shareholder rights index. However, while the UK and Australia also rank towards the top of the creditor rights index, the US and Canada rank towards the bottom. The resulting contrast in country-level dividend policies is instructive. The typical UK and Australian firm is $87 \%$ more likely to be a dividend-paying firm than its US and Canadian counterpart. Similarly, the typical UK and Australian firm pays out almost 2.80 times more dividends (as a percent of sales) than its US and Canadian counterpart. Weak creditor rights lead to lower dividend payouts even after controlling for shareholder rights. We confirm this same pattern in subsequent tests using cross-sectional regressions, a much larger sample, and multiple control variables.

In their survey article, Denis and McConnell (2003) identify La Porta, Lopez-de-Silanes, Shleifer, and Vishny (1998) study as the beginning of a new generation of research in international corporate governance. Numerous subsequent studies have examined the economic consequences of a firm's legal and institutional setting. Country-level shareholder rights have been linked to corporate investment policies (Love, 2003); capital market development (La Porta, Lopez-de-Silanes, Shleifer, and Vishny1997; Morck, Yeung, and Yu, 2000; Wurgler, 2000); ownership structure (La Porta et al., 1998, 1999; Claessens, Djankov, and Lang, 2000); expropriation (Johnson, La Porta, Lopez-de-Silanes, and Shleifer, 2000); corporate valuations (La Porta, Lopezde-Silanes, Shleifer, and Vishny, 2002); cash holdings (Dittmar, Mahrt-Smith, and Servaes, 2003; Pinkowitz, Stulz, and Williamson, 2003); and dividend policies (La Porta, Lopez-de-Silanes, Shleifer, and Vishny, 2000; Faccio, Lang, and Young, 2001). All of these studies suggest that shareholder rights affect corporate decisions because they provide the rules of the game for competing interests among disparate owners.

We extend this line of research by examining the ability of creditor rights to reduce the agency costs of debt. We claim that creditor rights will affect corporate decisions because they provide the ground rules for competing interests between debt and equity claimants. Previous studies have examined the impact of agency costs of debt on dividend policies while, in effect, holding constant the creditor rights environment (Smith and Warner, 1979; Kalay, 1982; Easterbrook, 1984). However, the extent to which countrylevel creditor rights determine dividend payouts is an open empirical question.

There are several reasons for creditors to demand additional control rights when creditor rights are weak. With inadequate legal protection, creditors are not confident in their ability to recover claims during bankruptcy proceedings. If a country's bankruptcy law grants an automatic stay on assets, for example, this increases creditors' costs of repossessing collateralized assets. If creditors are not given absolute priority over non-secured claimants during bankruptcy, their chances of full recovery are diminished. Similarly, some bankruptcy codes allow the distressed firm to unilaterally file for reorganization. Other codes allow incumbent management to remain in charge during prolonged bankruptcy periods. In such cases, creditors will be forced to negotiate with intransigent managers who have the motive and opportunity to threaten protracted bankruptcy proceedings in order to extract concessions.

If bankruptcy rights fail to provide adequate protection, creditors will demand greater control rights. Nini, Smith, and Sufi $(2007$, p. 1) show that "creditors draw from a toolkit of contractual covenants that can control or restrict nearly any dimension of corporate financial and investment policy". Creditor control rights are strongest for firms with private credit agreements (e.g., bank loans, revolving credit facilities), as opposed to firms with access to the public bond market. ${ }^{3}$ They show that only $15-20 \%$ of publicly traded firms in the US have access to the public bond market, and $95 \%$ of the firms still maintain some form of private credit agreement. These numbers are likely to understate the importance of private credit agreements and

\footnotetext{
${ }^{1}$ Esty and Megginson (2003) find that creditors are more likely to form large and diffuse syndicates when lending in environments with weak legal enforcement of creditor rights. Creditors use these syndicates as a substitute mechanism for poor creditor rights.

2 The cross-country correlation between creditor rights and shareholder rights is $18 \%(p$-value $=0.13)$ based on the 70 common countries that appear in both Djankov, McLiesh, and Shleifer (2007) and Djankov, La Porta, Lopez-de-Silanes, and Shleifer (2008).

${ }^{3}$ Studies related to bond covenants based on the U.S. (Smith and Warner, 1979; Kalay, 1982; Malitz, 1986), the UK (Citron, 1992, 1995; Day and Taylor, 1996), Germany (Leuz, Deller, and Stubenrath, 1998), Australia (Whittred and Zimmer, 1986; Mather and Peirson, 2006), Canada (Thornton, 1992), and Finland (Niskanen and Niskanen, 2004) suggest that creditors indeed take preventive measures that directly and/or indirectly restrict dividend payouts. Direct restrictions typically include an upper bound on the total dividend amount over the life of the loan (Kalay, 1982; Leuz, Deller, and Stubenrath, 1998). The upper bound increases with the level of earnings and the proceeds from new equity issuances, and decreases with the amount of previous dividend payouts.
} 
creditor control rights for firms operating in non-US markets. Creditors have a stronger incentive to exercise control over corporate decision-making through private credit agreements when they operate in environments with weak creditor protection. In such circumstances, both creditors and managers are more likely to agree to dividend restrictions as a counterbalance to poor creditor rights. ${ }^{4}$

We test the substitute hypothesis for the agency costs of debt by constructing a large sample of 120,507 firm-years from 16,525 unique firms across 52 countries. The sample period spans from 1990 to 2006 . We begin by examining the impact of creditor rights on the likelihood of paying dividends while controlling for firm maturity, leverage, profitability, sales growth, size, cash holdings, and shareholder rights. As hypothesized, we find a positive and significant relation between creditor rights and the probability of paying dividends. In addition to payout probabilities, we examine payout amounts. Our Tobit regression results show that creditor rights are positively related to divided payouts. ${ }^{5}$ Weak creditor rights lead to dividend restrictions, all else equal. We find similar results for most of the individual components of the creditor rights index, including the: (1) right to repossess collateralized assets, (2) right to absolute priority over non-secured creditors, (3) right to restrict the debtor from unilaterally seeking court protection, and (4) right to replace management.

We analyze the economic significance of our results and find that a reduction in the creditor rights index from its highest value (four) to its lowest value (zero) leads to a $41 \%$ reduction in the probability of paying a dividend. A similar reduction in creditor rights leads to a $60 \%$ reduction in dividend amounts (as a percent of sales). In contrast, an increase in minority shareholder rights from its lowest to its highest value leads to a $25 \%$ increase in the probability of paying a dividend and a $32 \%$ increase in dividend amounts. Cross-country variations in creditor rights have more explanatory power than cross-country variations in shareholder rights both in terms of statistical significance and economic significance.

After confirming the positive relation between creditor rights and dividend payouts, we examine additional implications of the substitute hypothesis. First, we compare the propensity of dividend-paying firms from low and high creditor rights countries to omit a future dividend payment. The substitute hypothesis suggests that managers from low creditor rights countries will be more likely to omit dividend payments whenever debt repayments are in jeopardy. Our empirical results strongly confirm this hypothesis. Second, we examine the interaction between creditor rights and credit quality. Firms with high credit quality have less need to use restrictive dividend payouts as an alternative governance mechanism (i.e., as a substitute for weak creditor rights). We posit and confirm that high credit quality reduces the influence of creditor rights on dividend payouts. Third, we analyze the interaction between creditor rights and free cash flows. The substitute hypothesis suggests that creditor rights will exert a stronger influence over dividend payouts when firms have positive free cash flows. Again, our empirical results confirm this hypothesis.

Next, we test an alternative explanation for our empirical findings. It is possible that the positive relation between creditor rights and dividend payouts is driven by poor access to external financing. If weak creditor rights discourage capital market development, then firms from such environments might pay lower dividends in order to finance projects from internal sources. We test this competing (though not mutually exclusive) hypothesis by analyzing the impact of dividend changes on firm valuations. Contrary to the prediction of this competing hypothesis, higher dividend payouts are not less value enhancing for firms from countries with poor creditor rights. Instead, our results confirm that creditor rights affect dividend policy through their impact on the agency costs of debt.

Finally, we run a series of robustness tests. We include additional controls for legal origin, rule of law, accounting standards, as well as stock market and credit market development. We control for time-variation in the relation between dividends and firm-specific characteristics. We control for potential sample selection biases by replicating all regressions using numerous subsamples. We employ alternative estimation procedures including Fama and MacBeth (1973) regressions and country-mean regressions. In summary, all of our robustness tests verify that creditor rights play a significant role in determining dividend payout policy.

Our study contributes to the corporate payout literature by proposing and confirming the substitute hypothesis based on agency costs of debt. When a country's creditor rights are inadequate, firms use restrictive dividend policies as a substitute bonding mechanism. Our study also contributes to the nascent literature on creditor control rights. Contrary to "traditional thinking" in corporate finance, recent studies find that creditors exert significant control over corporate investment and financing policies (Nini, Smith, and Sufi, 2007; Roberts and Sufi, 2007). We extend this growing literature by showing that creditors exercise substantial control over dividend payout policies.

\footnotetext{
${ }^{4}$ Not all dividend restrictions are contractual. John and Nachman (1985) argue that managers have an incentive to build reputation capital by restricting dividends if they expect to tap credit markets in the future. Long, Malitz, and Sefcik (1994) provide supportive evidence for this reputation-building mechanism. We nevertheless collect debt covenant provisions from a DealScan database for a subsample of countries (the U.S., UK, and Canada) from 1993 to 2006 in order to examine dividend restrictions. We exclude loans to financial and utility companies, and then compare the frequency of debt covenants in a low creditor rights environment (the U.S. and Canada) to the frequency of debt covenants in a high creditor rights environment (the UK). Our results show that $87.3 \%$ (78.8\%) of U.S. (Canadian) loans contain dividend restrictions compared to $59.7 \%$ for UK loans. These frequency differences (i.e., U.S. versus UK, and Canada versus UK) are statistically significant ( $p$-values $<0.001$ ). We find similarly significant differences across creditor rights environments for covenants based on financial ratios and net worth restrictions. Taken together, this evidence supports the substitute hypothesis by showing that creditors demand more debt covenants, including dividend restrictions, as a substitute for weak creditor rights.

${ }^{5}$ We find similar logit and Tobit results using total payouts (dividends plus repurchases) as the dependent variable.
} 
The remainder of this paper is organized as follows. Section 2 describes our sample and variables. Section 3 analyzes our empirical findings, and Section 4 concludes the study.

\section{Data and variable descriptions}

\subsection{Data sources and sample selection}

Our primary data source for this study is Compustat Global. We obtain annual financial accounting variables, monthly market information, and monthly exchange rates from Compustat Global Industrial, Compustat Global Issues, and Compustat Global Currency files, respectively. We collect country-level variables through various sources. We obtain creditor rights, shareholder rights, and legal origin from Djankov, McLiesh, and Shleifer (2007) and Djankov, La Porta, Lopez-de-Silanes, and Shleifer. (2008) - two studies that update the La Porta, Lopez-deSilanes, Shleifer, and Vishny (1998) database. We obtain rule of law measures from Kaufmann, Kraay, and Mastruzzi (2003). Our accounting quality disclosure scores are based on two sources, Hope, Kang, and Zang (2004) and Bhattacharya, Daouk, and Welker (2003). The accounting disclosure scores are from the Center for International Financial Analysis and Research (CIFAR). We construct stock market and financial intermediary development measures (Demirguc-Kunt and Levine, 1996) from the World Development Indicators CD-ROM produced by the World Bank.

We begin our sample construction by matching the Compustat Global Industrial database to the Compustat Global Issues database. We require that each firm-year observation in the annual Global Industrial file has: (1) fully consolidated accounting statements (consol $=\mathrm{F}$ in Compustat Global Industrial), (2) membership in a non-regulated industry, ${ }^{6}$ (3) long-term debt, and (4) all the data fields required for subsequent analyses. After applying these filters, we obtain a sample of 120,507 firm-year observations from 16,525 unique firms across 52 countries during the period 1990-2006. We also construct a subsample to test the valuation impact of creditor rights using the approach of Fama and French (1998). Because this method requires a five-year period of firm-specific data, this subsample contains 67,331 firm-year observations from 12,052 unique firms across 50 countries during the period 1992-2004.

\subsection{Variables}

In this section, we define all the variables used in our empirical tests. Since most variables are from accounting statements, data items shown in the parentheses apply to Compustat Global Industrial file, unless otherwise stated.
We describe our dependent and independent variables in the following subsections.

\subsubsection{Dependent variables}

We examine the impact of creditor rights on the probability of paying dividends and on dividend amounts using logit, Tobit, and ordinary least squares (OLS) specifications. For the logit models, we create a dividend-payer dummy, PAYER, which equals one if total dividends paid (data 34) are positive, and zero otherwise. For the Tobit specifications, we measure dividend amounts, DIV_TO_ $S$, by scaling total dividends paid (data 34 ) by sales (data 1). ${ }^{7}$ We scale dividends by sales instead of earnings for two reasons. First, when earnings are negative, the payout ratio becomes meaningless. Although eliminating firm-years with negative-earnings solves this problem, such remedy reduces the sample size by more than $7.5 \%$. Second, Leuz, Nanda, and Wysocki (2003) find that earnings management varies internationally and the scope of earnings management is negatively correlated to the strength of investor rights. Therefore, for maximum sample size and minimum measurement error, we use a sales-scaled payout ratio. ${ }^{8}$

\subsubsection{Independent variables}

Our independent variables are grouped into two categories: country-specific variables and firm-specific variables. The main country-specific variables are the creditor rights index, $C R$, as well as the individual components of this index. The creditor rights index is computed by summing four dummy variables. The first dummy variable, NO_AUTOSTAY, equals one if there is no automatic stay on assets, and zero otherwise. The second dummy variable, SECURED_FIRST, equals one if secured creditors are given the absolute priority claims during bankruptcy. SECURED_FIRST equals zero if government or employee claims have higher priority than those of secured creditors. The third dummy variable, RESTRICT_REORG, equals one if management cannot file for reorganization unilaterally. RESTRICT_REORG equals zero if creditor consent is not required to file for reorganization. The fourth dummy variable, MGMT_NOT_STAY, equals one if either creditors or courts can change the incumbent management during bankruptcy proceedings. If management has the power to remain in charge during bankruptcy proceedings, then we set MGMT_NOT_STAY equal to zero. ${ }^{9}$

Our other country-specific measures include shareholder rights, civil law origin dummy, the rule of law, accounting standards, and financial development indicators. The shareholder rights index, $A D$, measures the strength of control rights granted by law to the minority shareholders. ${ }^{10}$ Kaufmann, Kraay, and Mastruzzi (2003) rule of

\footnotetext{
${ }^{6}$ We eliminate utilities and financial firms with two-digit North American Industry Classification System (NAICS) codes of 22 and 52, respectively.

${ }^{7}$ We supplement any missing items for dividends paid (data 34) with the total amount of dividends paid during the fiscal year from the issues file.

${ }^{8}$ We re-run all tests using the reduced sample with dividends scaled by earnings and with dividends scaled by cash flows. Our results are similar to those reported herein for dividends scaled by sales.

${ }^{9}$ Our findings and conclusions are robust to using Djankov, Hart, McLiesh, and Shleifer (2006) definition of bankruptcy-cost efficiency as a proxy for creditor rights.

${ }^{10}$ Similar to the creditor rights index, the shareholder rights index is an accumulation of six dummy variables corresponding to various aspects of control rights (La Porta, Lopez-de-Silanes, Shleifer, and Vishny, 1998). As a robustness check, we also use La Porta, Lopez-de-Silanes, and
} 
law index captures the degree to which citizens have confidence in, and are bounded by, the rules of their society. This index includes "perceptions of the incidence of crime, the effectiveness and predictability of the judiciary, and the enforceability of contracts". We use two dummy variables to measure accounting standards. Our low accounting standards dummy equals one if the disclosure score of the firm's country is in the bottom global quartile, otherwise zero. Our high accounting standards dummy equals one if the disclosure score of the firm's country is in the top global quartile, otherwise zero.

Following Demirguc-Kunt and Levine (1996), we use two measures of financial development. The first measure captures stock market development and is computed by averaging standardized values of market capitalization to gross domestic product (GDP), total value traded to GDP, and total value traded to market capitalization ratios. The second measure captures financial intermediary development and equals the average of standardized values of liquid liabilities to GDP and domestic credit for private firms to GDP ratios. ${ }^{11}$

We use six variables to control for firm-specific characteristics. These widely used controls include retained earnings $(R E)$, equity ratio (TE), profitability $(R O A)$, sales growth (SGR), market capitalization (LOGSIZE), and cash holdings (CASH). RE is the retained earnings (data 131) divided by the book value of assets (data 89); TE is shareholders' equity (data 135) scaled by book value of assets (data 89); $R O A$ is net income (data 32) scaled by book value of assets (data 89); SGR is the logarithmic sales growth computed as $\log \left(\right.$ data $1_{t} /$ data $\left.1_{t-1}\right)$; LOGSIZE is the natural logarithm of the market value of equity computed at the fiscalyear end in billions \$US; and CASH equals the cash balance (data 61) scaled by book value of assets (data 89). All of our firm-specific variables are computed at fiscal year-end. The predicted signs between our firm-specific variables and dividends are as follows: retained earnings $(+)$, equity-ratio $(+/-)$, profitability $(+)$, sales growth $(-)$, market capitalization $(+)$, and cash holdings $(+/-) .{ }^{12}$

\section{Empirical results}

\subsection{Summary statistics}

We provide summary statistics for the main sample in Panel A of Table 1. The mean value for our payer dummy variable is $64.40 \%$, suggesting that the sample has a major- ity of dividend-paying firms. The mean (median) dividendto-sales ratio is $1.20 \%(0.50 \%)$. A considerable number of firm-years $(35,850)$ contain non-positive retained earnings. This finding is consistent with the fact that $35.60 \%$ of our sample firms do not pay dividends. ${ }^{13}$ The variation of our variables from $5 \%$ to $95 \%$ of the empirical distribution looks reasonable and does not suggest a selection bias. For example, our sample includes small firms with assets of \$20.96 million $\left(1000 \times e^{-3.865}=\$ 20.96\right.$ million) at the 5\% breakpoint, and large firms with assets of $\$ 8.85$ billion $\left(1000 \times e^{2.180}=\right.$ $\$ 8.85$ billion) at the $95 \%$ breakpoint. Similarly reasonable magnitudes apply to the other variables as well.

In Panel B we report the number of firm observations by year. The number of firms in our sample increases considerably throughout the 1990s, reaches a peak in 2001, and generally declines thereafter. These numbers appear to reflect the booming stock market during the 1990s, followed by the post-bubble bust around the turn of the century.

In Panel $C$ we present the distribution of firms across industries. More than half of the firms belong to the manufacturing industry. Besides manufacturing, five other industries have a sample size above 5,000 observations; construction $(5,392)$, wholesale trade $(7,344)$, retail trade $(7,561)$, information $(8,344)$, and professional, scientific, and technical services $(5,925)$. The only industry with less than 300 observations is the management of companies and enterprises category with 89 firm-years.

In Panel D we report the distribution of firms across countries. There are 34 civil law countries and 18 common law countries in our sample. Consistent with La Porta, Lopez-de-Silanes, Shleifer, and Vishny (2000), firms in common law countries are more likely to pay dividends than firms in civil law countries $(78.82 \%$ versus $68.55 \%$, respectively). Similarly, firms in common law countries pay larger dividends than firms in civil law countries $(2.22 \%$ versus $1.53 \%$ of sales, respectively). We also note that over half of our sample firm-years are from three countries: US $(38,684)$, Japan $(23,044)$, and the UK $(10,367)$. This skewness is present in most international studies regardless of the data vendor. ${ }^{14}$ We show that our results are unaffected by the disproportionate presence of US, Japanese, and UK firms in a subsequent section.

The results in Panel D highlight the issue raised in our introduction. Australia, the UK, and Canada are all common law countries with similar shareholder rights but dissimilar creditor rights. In the countries with the stronger

Shleifer (2006) ex ante and ex post investor protection measures and Djankov, La Porta, Lopex-de-Silanes, and Shleifer (2008) anti-self-dealing index as proxies for shareholder rights. Our creditor rights findings are unaffected by these alternative proxies.

${ }^{11}$ Consistent with Demirguc-Kunt and Levine (1996), we standardize each component of the development measures by dividing the demeaned variable by the absolute value of the global average of that variable.

${ }^{12}$ DeAngelo, DeAngelo, and Stulz (2006) argue that predicted signs for equity-ratios and cash holdings are ambiguous. A firm with a low equity ratio might be in financial trouble and therefore not pay dividends. A firm with a high equity ratio might not pay dividends because it is a startup firm. Similarly, firms can have high cash holdings due to accumulated free cash flows, or due to the need to finance future growth. In the first case, firms are likely to pay dividends and in the second they are not.

${ }^{13}$ This is consistent with the life-cycle explanation of dividends of DeAngelo and DeAngelo (2006), DeAngelo, DeAngelo, and Stulz (2006), and Denis and Osobov (2008).

${ }^{14}$ La Porta, Lopez-de-Silanes, Shleifer, and Vishny (2000), for example, extract their data from Worldscope, and Dittmar, Mahrt-Smith, and Servaes (2003) use Compustat Global. Both studies have a similarly disproportionate number of observations from the U.S., UK, and Japan. 
Table 1. Summary statistics.

Panels A and B show the summary statistics for the overall sample and annual number of observations. Panel C shows the industry breakdown of the sample and Panel D shows the country level shareholder and creditor rights (as of 2006), proportion of payers, and mean dividend-to-sales ratio. The sample period is 1990-2006. PAYER $R_{t}$ equals one if the firm pays dividends (data 34>0), otherwise equals zero. DIV_TO_S is the ratio of dividends (data 34) to sales (data 1). $R E_{t}$ is retained earnings (data 131) scaled by the book value of assets (data 89). TE $E_{t}$ is the shareholders' equity (data 135) scaled by the book value of assets (data 89). $R O A_{t}$ is net income (data 32) scaled by the book value of assets (data 89). $S G R_{t}$ is the logarithmic sales growth computed as $\log \left(\right.$ data $1_{t} /$ data $\left.1_{t-1}\right)$. LOGSIZE $E_{t}$ is the natural logarithm of the book value of assets (data 89 ) in billions of $\$$ US. $C A S H_{t}$ is the cash balance (data 61) scaled by the book value of assets (data 89). CR and $A D$ are the creditor and shareholder rights from Djankov, McLiesh, and Shleifer (2007) and Djankov, La Porta, Lopez-de-Silanes, and Shleifer (2008), respectively.

\section{Panel A: Firm-specific data}

\begin{tabular}{lcrrrrrrr}
\hline Variable & $N \leq 0$ & $N$ & Mean & Median & $5 \%$ & $25 \%$ & $75 \%$ & $95 \%$ \\
\hline PAYER & - & 120,507 & 0.644 & 1.000 & 0.000 & 0.000 & 1.000 & 1.000 \\
DIV_TO_S & - & 120,507 & 0.012 & 0.005 & 0.000 & 0.000 & 0.017 & 0.061 \\
RE & 35,850 & 120,507 & 0.068 & 0.097 & -0.853 & 0.000 & 0.249 & 0.505 \\
TE & - & 120,507 & 0.423 & 0.421 & 0.056 & 0.282 & 0.566 & 0.780 \\
ROA $_{t}$ & 29,360 & 120,507 & 0.015 & 0.028 & -0.227 & 0.001 & 0.061 & 0.131 \\
SGR & 40,306 & 120,507 & 0.087 & 0.075 & -0.320 & -0.048 & 0.200 & 0.580 \\
LOGSIZE $_{t}$ & - & 120,507 & -1.024 & -1.104 & -3.865 & -2.266 & 0.157 & 2.180 \\
CASH $_{t}$ & - & 120,507 & 0.080 & 0.052 & 0.001 & 0.018 & 0.116 & 0.287
\end{tabular}

Panel B: Annual number of observations

\begin{tabular}{llllllllllll}
\hline Year & $N$ & Year & $N$ & Year & $N$ & Year & $N$ & Year & $N$ & Year & $N$ \\
\hline 1990 & 3,887 & 1993 & 4,622 & 1996 & 6,670 & 1999 & 9,490 & 2002 & 9,751 & 2005 & 6,653 \\
1991 & 4,098 & 1994 & 5,387 & 1997 & 7,779 & 2000 & 9,677 & 2003 & 9,529 & 2006 & 5,732 \\
1992 & 4,265 & 1995 & 6,072 & 1998 & 9,292 & 2001 & 9,804 & 2004 & 7,799 &
\end{tabular}

Panel C: Industry distribution

\begin{tabular}{lrr}
\hline NAICS Industry definition & Two-digit NAICS code & $N$ \\
\hline Agriculture, forestry, fishing and hunting & 11 & 1,047 \\
Mining & 21 & 4,782 \\
Construction & 23 & 5,392 \\
Manufacturing & $31-33$ & 64,750 \\
Wholesale trade & 42 & 7,344 \\
Retail trade & $44-45$ & 7,561 \\
Transportation and warehousing & $48-49$ & 5,095 \\
Information & 51 & 8,344 \\
Real estate and rental and leasing & 53 & 1,834 \\
Professional, scientific, and technical services & 54 & 5,925 \\
Management of companies and enterprises & 55 & 89 \\
Administrative and support and waste management & 56 & 2,185 \\
Educational services & 61 & 347 \\
Health care and social assistance & 62 & 1,554 \\
Arts, entertainment, and recreation & 71 & 1,019 \\
Accommodation and food services & 72 & 2,786 \\
Other services (except public administration) & 81 & 453
\end{tabular}

Total

120,507

Panel D: Country-level data

\begin{tabular}{|c|c|c|c|c|c|}
\hline Country & $N$ & $\mathrm{AD}$ & $\mathrm{CR}$ & PAYER (\%) & DIV_TO_S (\%) \\
\hline Australia & 2,760 & 4 & 3 & 81.52 & 2.95 \\
\hline Canada & 4,990 & 4 & 1 & 46.45 & 1.08 \\
\hline Ghana & 4 & 5 & 1 & 75.00 & 3.01 \\
\hline India & 504 & 5 & 2 & 88.89 & 2.28 \\
\hline Ireland & 477 & 4 & 1 & 81.55 & 1.43 \\
\hline Israel & 259 & 4 & 3 & 50.97 & 1.43 \\
\hline New Zealand & 365 & 4 & 4 & 81.37 & 3.02 \\
\hline Pakistan & 158 & 4 & 1 & 78.48 & 2.97 \\
\hline Singapore & 2,665 & 5 & 3 & 75.01 & 1.92 \\
\hline South Africa & 769 & 5 & 3 & 84.01 & 2.19 \\
\hline Sri Lanka & 15 & 4 & 2 & 100.00 & 1.28 \\
\hline
\end{tabular}


Table 1 (continued).

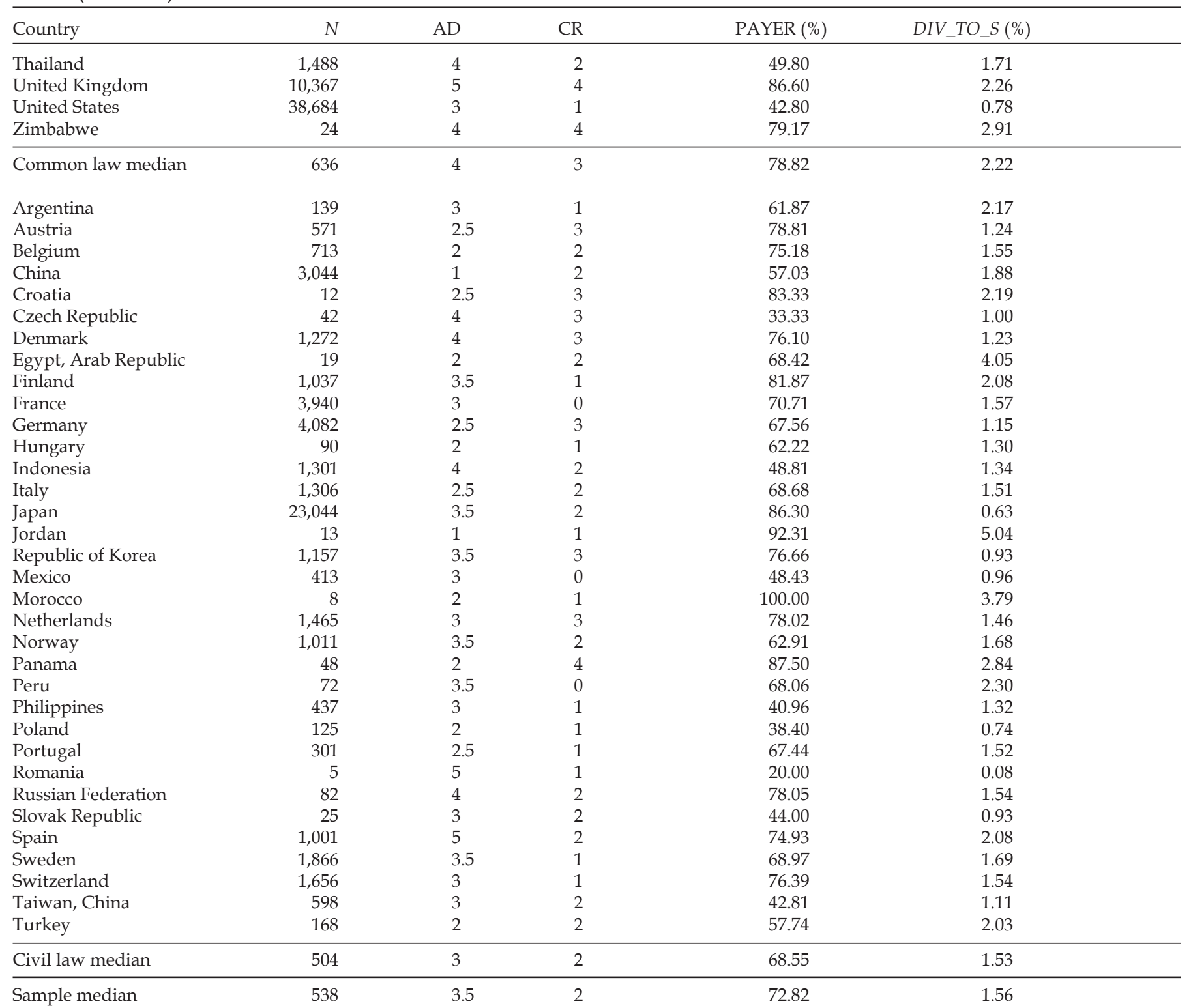

creditor rights, Australia (three) and the UK (four), 81.52 and $86.60 \%$ of firms pay dividends, respectively, while the median dividend-to-sales ratios are $2.95 \%$ and $2.26 \%$, respectively. In Canada, with a low creditor rights score of one, only $46.45 \%$ of firms pay dividends and the median dividend-to-sales ratio is $1.08 \%$. This anecdotal evidence is consistent with our hypothesized relation between creditor rights and dividend payouts.

\subsection{Creditor rights and dividend payouts}

In this section, we examine the relation between creditor rights and two dividend policy variables: (1) the likelihood of paying dividends and (2) the amount of dividends paid. We present the results of logit, Tobit, and OLS regressions including control variables motivated by previous research. ${ }^{15}$

3.2.1. Multivariate logit analysis: creditor rights and the propensity to pay

In Table 2 we present our logit results based on unadjusted industry data. Our logit model is specified as follows (with firm subscripts suppressed):

$$
\begin{aligned}
& \operatorname{Prob}_{\text {Payer } \left._{t}=1\right)} \\
& \quad=F\left(\alpha_{1}+\alpha_{2} R E_{t}+\alpha_{3} \text {TE}_{t}+\alpha_{4} \text { ROA }_{t}+\alpha_{5} S G R_{t}\right. \\
& \left.\quad+\alpha_{6} \text { LOGSIZE }_{t}+\alpha_{7} \mathrm{CASH}_{t}+\alpha_{8} A D+\alpha_{9} C R_{t}\right)
\end{aligned}
$$

\footnotetext{
${ }^{15}$ We examine the stability of our results by replicating the estimations on various winsorized samples including $1 \%, 5 \%$, and $10 \%$. The statistical and economic significance of our coefficients is very similar in each set of replications, suggesting that outliers do not drive our results. We report all results based on $5 \%$ winsorization.
} 
where Payer takes the value of one if the firm (index suppressed) paid a dividend in year $t$, and zero otherwise. All other variables are described above. We estimate four variations of regression Eq. (1) and report the results in columns 1-4 of Table 2, respectively.

In Model 1 we estimate the likelihood of paying dividends as a function of creditor rights alone. The estimated coefficient of 0.52404 for the creditor rights index is positive and highly significant, consistent with the substitute hypothesis. The likelihood of paying dividends increases with creditor rights; that is, weak creditor rights lead managers to substitute restrictive dividend policies for poor creditor protection.

In Model 2 we include firm-specific control variables, as well as a country-level shareholder rights index. The results show that firms with higher retained earnings, profitability, and market capitalizations are more likely to pay

Table 2. Creditor rights and the likelihood of paying dividends.

This table presents the pooled fixed-effect logit regression results with firm-level clustered errors. Sample period is 1990-2006. The dependent variable, $P A Y E R_{t^{\prime}}$ equals one if the firm pays dividends (data $34>0$ ), otherwise equals zero. $R E_{t}$ is retained earnings (data 131) scaled by the book value of assets (data 89). $T E_{t}$ is the shareholders' equity (data 135) scaled by the book value of assets (data 89). $R O A_{t}$ is net income (data 32) scaled by the book value of assets (data 89). $S G R_{t}$ is the logarithmic sales growth computed as $\log \left(\right.$ data $1_{t} /$ data $\left.1_{t-1}\right)$. LOGSIZE $E_{t}$ is the natural logarithm of the book value assets (data 89) in billions of \$US. $\mathrm{CASH}_{t}$ is the cash balance (data 61) scaled by the book value of assets (data 89). $C R_{t}$ and $A D$ are creditor and shareholder rights from Djankov, McLiesh, and Shleifer (2007) and Djankov, La Porta, Lopez-de-Silanes, and Shleifer (2008), respectively.

\begin{tabular}{|c|c|c|c|c|}
\hline \multirow{2}{*}{$\begin{array}{l}\text { Independent variables } \\
\text { (Predicted sign) }\end{array}$} & \multicolumn{4}{|c|}{ Dependent variable $=P A Y E R_{t}$} \\
\hline & (1) & (2) & (3) & (4) \\
\hline Intercept & $\begin{array}{l}-0.36103 \\
(<0.001)\end{array}$ & $\begin{array}{l}-0.75887 \\
(<0.001)\end{array}$ & $\begin{array}{l}-0.47316 \\
(<0.001)\end{array}$ & $\begin{array}{c}0.09226 \\
(0.706)\end{array}$ \\
\hline$R E_{t}(+)$ & & $\begin{array}{r}2.85445 \\
(<0.001)\end{array}$ & $\begin{aligned} & 2.81546 \\
&(<0.001)\end{aligned}$ & $\begin{array}{c}2.69249 \\
(<0.001)\end{array}$ \\
\hline$T E_{t}(+/-)$ & & $\begin{array}{l}-0.60367 \\
(<0.001)\end{array}$ & $\begin{array}{l}-0.58516 \\
(<0.001)\end{array}$ & $\begin{array}{l}-0.46108 \\
(<0.001)\end{array}$ \\
\hline$R O A_{t}(+)$ & & $\begin{array}{c}7.61728 \\
(<0.001)\end{array}$ & $\begin{aligned} & 7.48851 \\
&(<0.001)\end{aligned}$ & $\begin{array}{c}7.47994 \\
(<0.001)\end{array}$ \\
\hline$S G R_{t}(-)$ & & $\begin{array}{l}-0.97462 \\
(<0.001)\end{array}$ & $\begin{array}{l}-0.96546 \\
(<0.001)\end{array}$ & $\begin{array}{l}-0.85727 \\
(<0.001)\end{array}$ \\
\hline LOGSIZE $_{t}(+)$ & & $\begin{array}{c}0.32669 \\
(<0.001)\end{array}$ & $\begin{array}{c}0.32863 \\
(<0.001)\end{array}$ & $\begin{array}{c}0.34219 \\
(<0.001)\end{array}$ \\
\hline $\mathrm{CASH}_{t}(+/-)$ & & $\begin{array}{c}-0.40304 \\
(0.034)\end{array}$ & $\begin{array}{c}-0.39383 \\
(0.041)\end{array}$ & $\begin{array}{c}-0.38250 \\
(0.050)\end{array}$ \\
\hline$A D(+)$ & & $\begin{array}{c}0.20711 \\
(<0.001)\end{array}$ & $\begin{array}{c}0.20634 \\
(<0.001)\end{array}$ & $\begin{array}{c}0.22567 \\
(<0.001)\end{array}$ \\
\hline$C R_{t}(+)$ & $\begin{array}{c}0.52404 \\
(<0.001)\end{array}$ & $\begin{array}{c}0.58004 \\
(<0.001)\end{array}$ & $\begin{array}{l}0.58993 \\
(<0.001)\end{array}$ & $\begin{array}{l}0.57329 \\
(<0.001)\end{array}$ \\
\hline Year fixed effects & No & No & Yes & Yes \\
\hline Industry fixed effects & No & No & No & Yes \\
\hline Pseudo- $R^{2}$ & 0.053 & 0.274 & 0.277 & 0.281 \\
\hline
\end{tabular}

dividends, consistent with expectations. In addition, firms with higher equity-to-asset ratios, sales growth, and cash holding are less likely to pay dividends. The signs of these control variables are also consistent with expectations. Similar to La Porta, Lopez-de-Silanes, Shleifer, and Vishny (2000) findings related to the outcome hypothesis, we find a positive and significant relation between shareholder rights and the likelihood of paying dividends. Our main variable of interest, creditor rights, has a positive and highly significant coefficient of 0.58004 . This coefficient is 2.8 times the magnitude of the shareholder rights coefficient of 0.20711 . We also note that the Pseudo- $R^{2}$ for Model 2 is $27.40 \%$, a substantial increase from Model 1's $5.30 \%$.

In Model 3 we examine the relation between the likelihood of dividend payments and creditor rights after controlling year fixed effects, along with our other control variables. In Model 4 we add industry fixed effects. ${ }^{16}$ The empirical results from Models 3 and 4 are quite similar to those from Model 2. That is, firms with higher retained earnings, profitability, and market capitalizations are more likely to pay dividends, while firms with higher equity-toasset ratios, sales growth, and cash holdings are less likely to pay dividends. We find a positive and significant relation between shareholder rights and the likelihood of paying dividends in both regressions, consistent with La Porta, Lopez-de-Silanes, Shleifer, and Vishny (2000) outcome hypothesis. More importantly, the creditor rights coefficient is always positive and highly significant.

Overall, our Table 2 results confirm the substitute hypothesis with respect to the agency costs of debt, creditor rights, and dividend policy. We also find evidence supportive of La Porta, Lopez-de-Silanes, Shleifer, and Vishny (2000) outcome hypothesis for the agency costs of equity, shareholder rights, and dividend policy. The highly significant creditor rights and shareholder rights coefficients in Models 2, 3, and 4, suggest that agency costs of both debt and equity play important, yet distinct, roles in shaping corporate dividend policy. Between the two, however, creditor rights has a larger impact on dividend policy.

\subsubsection{Economic significance of creditor rights and the propensity to pay \\ We explicitly analyze the economic significance of these re- sults in Figure 1. In the upper graph, we plot the predicted probabilities of paying dividends against creditor rights based on the full logit model (Model 4) from Table 2. We evaluate all independent variables at their sample medi- ans and evaluate the fixed effects for the year 2006 and the manufacturing industry. ${ }^{17}$ All else equal, the probability of paying dividends increases from $54 \%$ to $92 \%$ as the creditor rights index changes from zero to four. A typical firm from}

\footnotetext{
${ }^{16}$ In addition to industry fixed effects, we also adjust all firm-specific variables following the method of La Porta, Lopez-de-Silanes, Shleifer, and Vishny (2000) in order to account for any confounding effects attributable to industry differences. First, we compute the industry median for each variable at the country level. Second, we compute the median value of these first-stage medians across all countries. Third, we subtract the global industry median from each variable of interest. We then re-estimate our logit Eq. (1) using these industry-adjusted data. The results are consistent with those reported in Table 2.

${ }^{17}$ We also evaluate all independent variables at their sample medians and evaluate the year and industry fixed effects using alternative years and industries. Our results are not sensitive to the choice of year or industry fixed effects.
} 


\section{Probability of paying dividends}

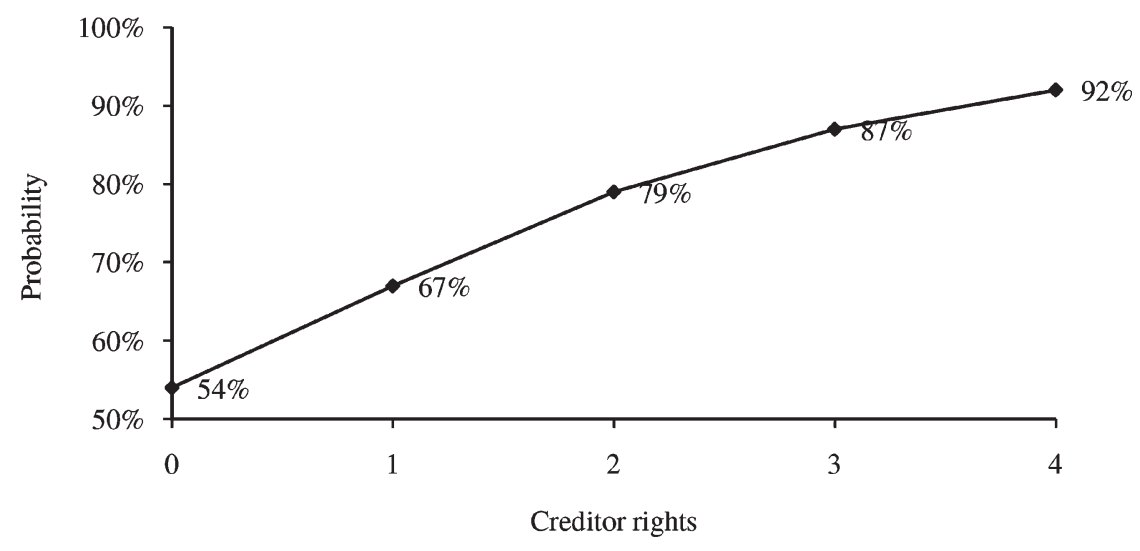

Probability of paying dividends

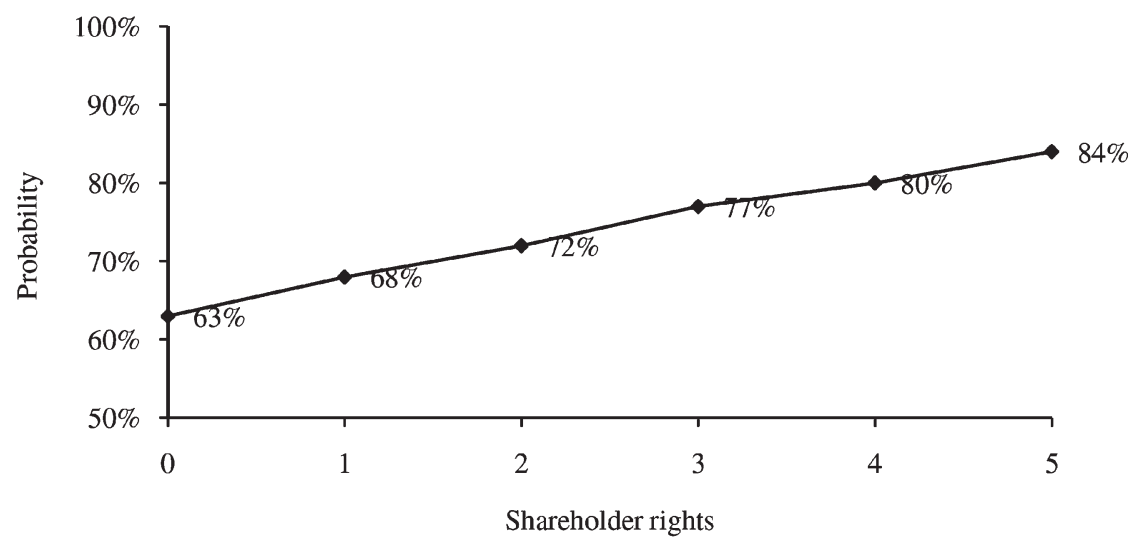

Figure 1. Economic significance of in-sample predictions for the probability of paying dividends. These two figures plot the predicted probabilities of paying dividends for alternative creditor rights $(C R)$ and shareholder rights $(A D)$ indexes using the logit model estimated as Model 4 in Table 2. All other independent variables are evaluated at the sample median. Year and industry dummies are evaluated for 2006 and for the manufacturing industry.

the highest creditor rights environment is over $70 \%$ more likely to pay dividends than a typical firm from the lowest creditor rights environment. Stated differently, a reduction in the creditor rights index from its highest value to its lowest value implies a $41 \%$ reduction in the probability of paying a dividend.

In the lower graph, we plot the predicted probabilities of paying dividends against shareholder rights based on the full logit model (Model 4) from Table 2. Again, we evaluate all independent variables at their sample medians and evaluate the fixed effects for the year 2006 and the manufacturing industry. Comparing the upper and lower graphs, we observe that the shareholder rights slope is substantially flatter than the creditor rights slope. The probability of paying dividends is less sensitive to changes in shareholder rights than to changes in creditor rights. The probability of paying dividends increases from $63 \%$ to $84 \%$ as the shareholder rights index changes from its lowest to its highest value. A typical firm from the highest shareholder rights environment is roughly $33 \%$ more likely to pay dividends than a typical firm from the lowest shareholder rights environment. Although shareholder rights play a significant role in dividend policy, their overall impact is weaker than that of creditor rights.

\subsubsection{Multivariate Tobit analysis: creditor rights and dividend amounts}

After finding that creditor rights increase the probability of paying dividends, we turn to the relation between creditor rights and dividend amounts. In Table 3, we report the results of Tobit regressions. Our Tobit model is specified as follows (with firm subscripts suppressed):

$$
\begin{aligned}
& D I V \_T O \_S_{t}=\alpha_{1}+\alpha_{2} R E_{t}+\alpha_{3} T E_{t}+\alpha_{4} R O A_{t} \\
& +\alpha_{5} S R_{t}+\alpha_{6} \text { LOGSIZE }_{t}+\alpha_{7} \mathrm{CASH}_{t} \\
& +\alpha_{8} A D+\alpha_{9} C R_{t}+\varepsilon_{t} \\
& D I V \_T O \_S_{t}= \begin{cases}D I V \_T O \_S_{t}^{*} & \text { if } D I V \_T O \_S_{t}^{*}>0 \\
0 & \text { otherwise }\end{cases}
\end{aligned}
$$

All variables are defined above. 
Table 3. Creditor rights and dividend amounts.

This table presents the pooled fixed-effect Tobit regression results. Sample period is 1990-2006. The dependent variable, DIV_TO_S ${ }^{\prime}$ is the ratio of dividends (data 34 ) to sales (data 1). $R E_{t}$ is retained earnings (data 131) scaled by the book value of assets (data 89). $T E_{t}$ is the shareholders' equity (data 135) scaled by the book value of assets (data 89). $R O A_{t}$ is net income (data 32) scaled by the book value of assets (data 89). $S G R_{t}$ is the logarithmic sales growth computed as log (data $1_{t} /$ data $1_{t-1}$ ). LOGSIZE $E_{t}$ is the natural logarithm of the book value of assets (data 89) in billions of \$US. CASH $H_{t}$ is the cash balance (data 61) scaled by the book value of assets (data 89). $C R_{t}$ and $A D$ are creditor and shareholder rights from Djankov, McLiesh, and Shleifer (2007) and Djankov, La Porta, Lopez-de-Silanes, and Shleifer (2008), respectively.

\begin{tabular}{|c|c|c|c|c|}
\hline \multirow{2}{*}{$\begin{array}{l}\text { Independent variables } \\
\text { (Predicted sign) }\end{array}$} & \multicolumn{4}{|c|}{ Dependent variable $=$ DIV_TO_ $S_{t}$} \\
\hline & (1) & $(2)$ & (3) & (4) \\
\hline Intercept & $\begin{array}{l}-0.00411 \\
(<0.001)\end{array}$ & $\begin{array}{l}-0.01348 \\
(<0.001)\end{array}$ & $\begin{array}{l}-0.01218 \\
(<0.001)\end{array}$ & $\begin{array}{l}-0.00755 \\
(<0.001)\end{array}$ \\
\hline$R E_{t}(+)$ & & $\begin{aligned} & 0.00937 \\
&(<0.001)\end{aligned}$ & $\begin{array}{l}0.00915 \\
(<0.001)\end{array}$ & $\begin{array}{l}0.01068 \\
(<0.001)\end{array}$ \\
\hline$T E_{t}(+/-)$ & & $\begin{aligned} & 0.01775 \\
&(<0.001)\end{aligned}$ & $\begin{array}{c}0.01783 \\
(<0.001)\end{array}$ & $\begin{array}{l}0.01573 \\
(<0.001)\end{array}$ \\
\hline $\mathrm{ROA}_{t}(+)$ & & $\begin{array}{l}0.11745 \\
(<0.001)\end{array}$ & $\begin{array}{l}0.11728 \\
(<0.001)\end{array}$ & $\begin{array}{c}0.11721 \\
(<0.001)\end{array}$ \\
\hline$S G R_{t}(-)$ & & $\begin{array}{l}-0.01017 \\
(<0.001)\end{array}$ & $\begin{array}{l}-0.01026 \\
(<0.001)\end{array}$ & $\begin{array}{l}-0.01081 \\
(<0.001)\end{array}$ \\
\hline $\operatorname{LOGSIZE}_{t}(+)$ & & $\begin{array}{c}0.00267 \\
(<0.001)\end{array}$ & $\begin{array}{c}0.00266 \\
(<0.001)\end{array}$ & $\begin{array}{c}0.00249 \\
(<0.001)\end{array}$ \\
\hline $\mathrm{CASH}_{t}(+/-)$ & & $\begin{array}{l}-0.02793 \\
(<0.001)\end{array}$ & $\begin{array}{l}-0.02828 \\
(<0.001)\end{array}$ & $\begin{array}{l}-0.02669 \\
(<0.001)\end{array}$ \\
\hline$A D(+)$ & & $\begin{aligned} & 0.00169 \\
&(<0.001)\end{aligned}$ & $\begin{array}{l}0.00166 \\
(<0.001)\end{array}$ & $\begin{array}{c}0.00147 \\
(<0.001)\end{array}$ \\
\hline$C R_{t}(+)$ & $\begin{array}{c}0.00533 \\
(<0.001)\end{array}$ & $\begin{array}{l}0.00439 \\
(<0.001)\end{array}$ & $\begin{array}{l}0.00445 \\
(<0.001)\end{array}$ & $\begin{array}{l}0.00451 \\
(<0.001)\end{array}$ \\
\hline Year fixed effects & No & No & Yes & Yes \\
\hline Industry fixed effects & No & No & No & Yes \\
\hline Right censored & 42,862 & 42,862 & 42,862 & 42,862 \\
\hline
\end{tabular}

The Tobit results for dividend amounts presented in Table 3 are similar to the logit results for dividend probabilities presented in Table 2. The estimated coefficient for the creditor rights index (0.00533) in Model 1 is positive and highly significant, consistent with the substitute hypothesis. The amount of dividends increases with creditor rights, suggesting that managers operating in environments with weak creditor rights restrict their dividend payouts as a substitute governance mechanism.

In Model 2 we include firm-specific control variables, as well as a country-level shareholder rights index. There is a positive and significant relation between dividend amounts and retained earnings, equity-to-asset ratios, profitability, and market capitalizations. There is a negative and significant relation between dividend amounts and sales growth and cash holdings. The signs of these control variables are consistent with expectations. We also confirm La Porta, Lopez-de-Silanes, Shleifer, and Vishny (2000) results by finding a positive and significant relation between shareholder rights and dividend amounts. More importantly, our creditor rights coefficient $(0.00439)$ is positive and highly significant. It is roughly 2.6 times the magnitude of the shareholder rights coefficient (0.00169).

In Model 3 we examine the relation between dividend amounts and creditor rights after controlling year fixed effects, along with our other control variables. In Model 4 we add industry fixed effects. The results from Models 3 and 4 confirm our findings from Model 2. More specifically, the control variables conform to expectations (including positive and significant shareholder rights coefficients) and the creditor rights coefficients are positive and highly significant.

Overall, the dividend amount results in Table 3 are consistent with the propensity to pay results in Table 2. Both sets of results support the substitute hypothesis. Although we find evidence for the outcome hypothesis with respect to the agency costs of equity (La Porta, Lopez-de-Silanes, Shleifer, and Vishny, 2000), we find stronger evidence for the substitute hypothesis with respect to the agency costs of debt.

\subsubsection{Economic significance: creditor rights and dividend amounts}

We examine the economic significance of these results in Figure 2. In the upper graph, we plot the predicted dividend payout ratios against creditor rights based on the Tobit model (Model 4) from Table 3. We evaluate all independent variables at their sample medians and evaluate the fixed effects for the year 2006 and the manufacturing industry. All else equal, as the creditor rights index increases from zero to four, the predicted payout ratio increases from $0.78 \%$ to $1.98 \%$ of firm sales. In relative terms, a change from $0.78 \%$ to $1.98 \%$ implies a 2.5 -fold increase in dividend payout ratios. Stated differently, a reduction in the creditor rights index from its highest value to its lowest value implies a $60 \%$ reduction in dividend payout ratios.

In the lower graph, we plot the predicted dividend payout ratios against shareholder rights based on the Tobit model (Model 4) from Table 3. Comparing the upper and lower graphs, we see that the shareholder rights slope is considerably flatter than the creditor rights slope. Dividend payout ratios are clearly less sensitive to changes in shareholder rights than to changes in creditor rights. These payout ratios increase from $0.99 \%$ of firm sales to $1.46 \%$ of firm sales as the shareholder rights index changes from its lowest to its highest value. Dividend payout ratios in the highest shareholder rights category are approximately 1.47 times larger than payout ratios in the lowest shareholder rights category.

\subsection{Creditor rights components}

We also examine the impact of individual components of the creditor rights index. As described earlier, the creditor rights index is comprised of four components: NO_AUTOSTAY which equals one if there is no automatic stay on assets, and zero otherwise; SECURED_FIRST which equals one if secured creditors are given the absolute priority during bankruptcy, and zero otherwise; RESTRICT_REORG which equals one if management cannot file for reorganization unilaterally, and zero otherwise; and MGMT_NOT_ STAY which equals one if either creditors or courts can change the incumbent management during bankruptcy proceedings, and zero otherwise. The main purpose of 


\section{Predicted dividend-to-sales ratio}

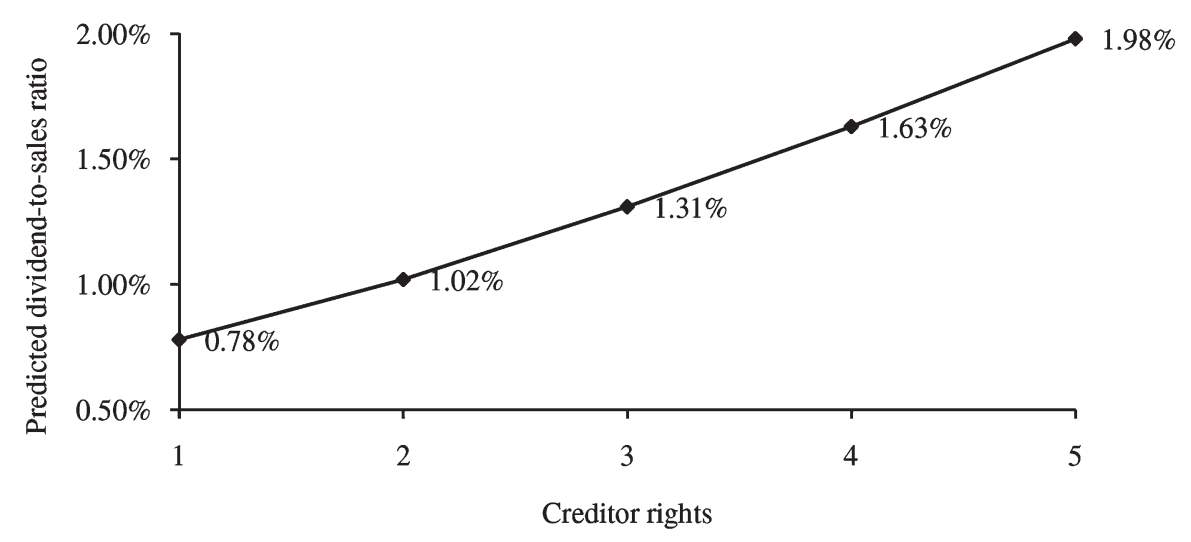

Predicted dividend-to-sales ratio

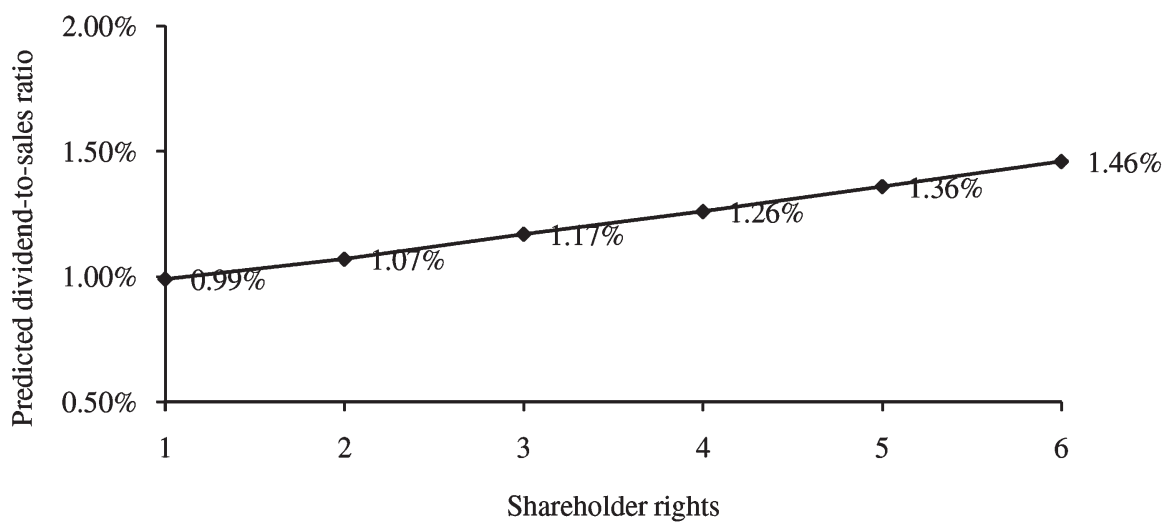

Figure 2. Economic significance of in-sample predictions for payout ratios. These two figures plot the predicted dividend-to-sales ratio for alternative creditor rights $(C R)$ and shareholder rights $(A D)$ indexes using the Tobit model estimated as Model 4 in Table 3 . All other independent variables are evaluated at the sample median. Year and industry dummies are evaluated for 2006 and for the manufacturing industry.

this analysis is to examine whether our previous results are driven by only one or two components of the index. In addition, these results will also provide some information about the relative importance of the four components.

In Table 4, we report logit results for each of the creditor rights components. The estimated coefficients for our control variables are consistent across all four regressions, as well as being consistent with the results in Table 2 and Table 3. In regressions 1,3 , and 4 , we find a positive and significant relation between the propensity to pay dividends and NO_AUTOSTAY (0.91587), RESTRICT_REORG (0.77483), and MGMT_NOT_STAY (1.32451), respectively. Among these positive coefficients, MGMT_NOT_STAY is over 40\% larger than NO_AUTOSTAY and over 70\% larger than RESTRICT_REORG. In regression 2, we find a negative and significant relation between the propensity to pay dividends and SECURED_FIRST (-0.57742). Although this is opposite of the predicted sign, we also note that there is very little variation in this component. Indeed, $94 \%$ of all SECURED_FIRST observations take a value of one. For the other three creditor rights components, $20.2 \%, 26.7 \%$, and $46.5 \%$ of their observations take a value of one.

\footnotetext{
${ }^{18}$ We thank an anonymous referee for suggesting this line of inquiry.
}

In Table 5, we report Tobit results for the creditor rights components. Similar to our Table 4 results, we find a positive and significant relation between the dividend payout amounts and NO_AUTOSTAY (0.0116), RESTRICT_REORG (0.01034), and MGMT_NOT_STAY (0.0062), respectively, and a negative and significant relation between dividend payouts and SECURED_FIRST (-0.00763). Again, the latter result is subject to the caveat that $94 \%$ of all observations take a value of one.

Overall, our results in Table 4 and Table 5 reveal that three out of four creditor rights categories are consistent with the composite index results in Table 2 and Table 3 . The evidence supports the substitute hypothesis with respect to NO_AUTOSTAY, RESTRICT_REORG, and MGMT_NOT_ STAY. Although it is possible to interpret the SECURED_ FIRST results as supportive of the outcome hypothesis, such a conclusion is probably overdrawn given distribution of the underlying creditor rights variable.

\subsection{Additional implications of the substitute hypothesis}

In the next three subsections, we further examine the testable implications of the substitute hypothesis. ${ }^{18}$ First, 
Table 4. Components of creditor rights and the likelihood of paying dividends.

This table presents the pooled fixed-effect logit regression results with firm-level clustered errors. Sample period is 1990-2006.The dependent variable, $P A Y E R_{t}$, equals one if the firm pays dividends (data $34>0$ ), otherwise equals zero. $R E_{t}$ is retained earnings (data 131 ) scaled by the book value of assets (data 89). $T E_{t}$ is the shareholders' equity (data 135) scaled by the book value of assets (data 89). ROA $A_{t}$ is net income (data 32 ) scaled by the book value of assets (data 89). SGR is the logarithmic sales growth computed as log (data $1_{t} /$ data $1_{t-1}$ ). LOGSIZE $E_{t}$ is the natural logarithm of the book value of assets (data 89) in billions of $\$ \mathrm{US}$. $\mathrm{CASH}_{t}$ is the cash balance (data 61) scaled by the book value of assets (data 89). $A D$ is shareholder rights index from Djankov, La Porta, Lopez-de-Silanes, and Shleifer (2008). NO_AUTOSTAY equals one if there is no automatic stay on the secured creditors' assets, otherwise equals zero. SECURED_FIRST equals one if the secured creditors are given the priority of the claims during the bankruptcy. RESTRICT_REORG equals one if the management of the firm cannot file for reorganization unilaterally.MGMT_NOT_STAY equals one if either creditors or court can change the incumbent management during bankruptcy proceeding.

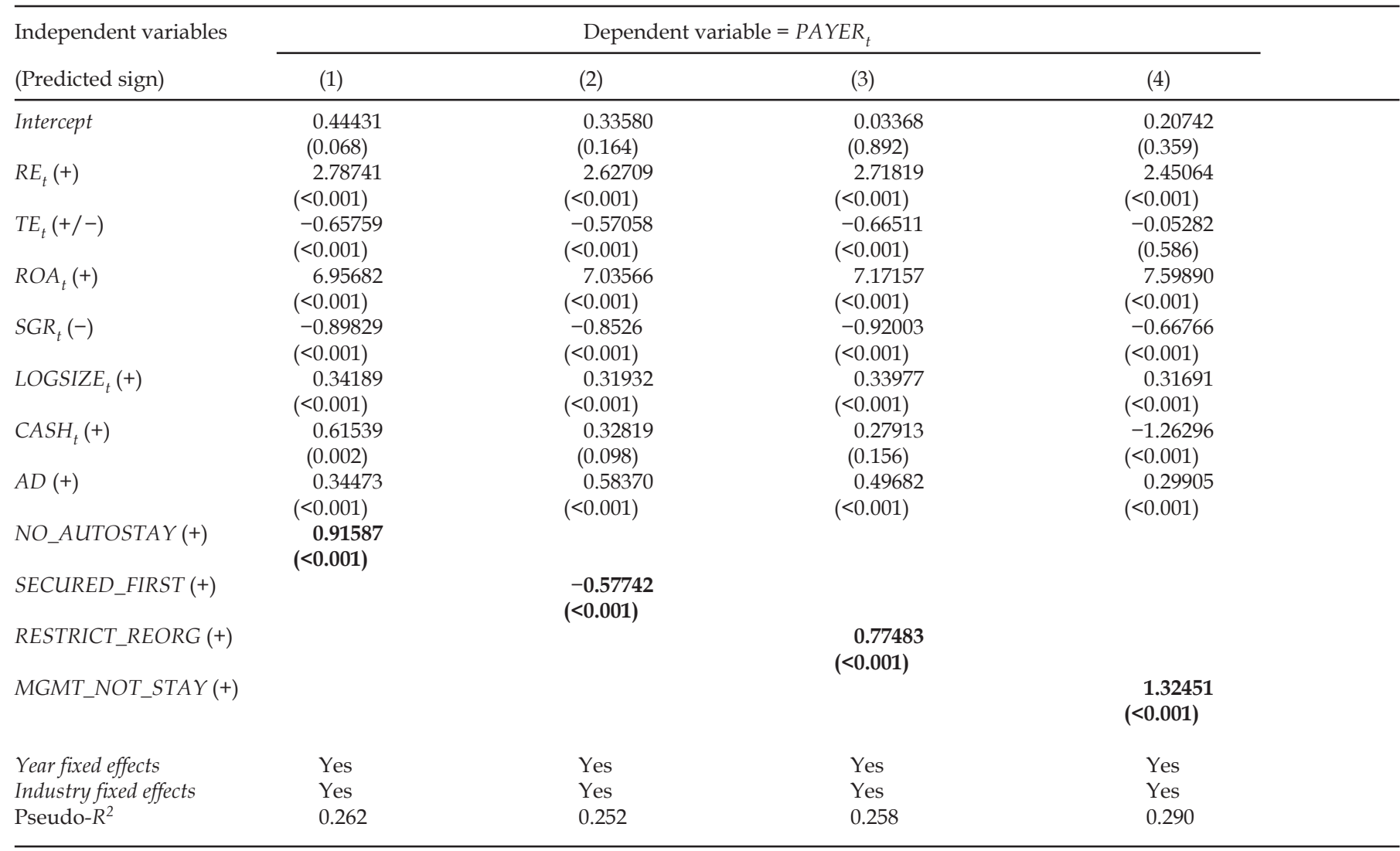

\begin{tabular}{lllll} 
& \multicolumn{4}{c}{ Sample distribution for components of creditor rights } \\
\cline { 2 - 5 } & NO_AUTOSTAY & SECURED_FIRST & RESTRICT_REORG & MGMT_NOT_STAY \\
\hline \# (\%) of observations with value $=0$ & 88,309 & 7,256 & 96,209 & 64,509 \\
& $(73.3 \%)$ & $(6.0 \%)$ & $(78.8 \%)$ & $(53.5 \%)$ \\
\# (\%) of observations with value $=1$ & 32,198 & 113,251 & 24,298 & 55,998 \\
& $(26.7 \%)$ & $(94.0 \%)$ & $(20.2 \%)$ & $(46.5 \%)$ \\
\hline
\end{tabular}

we compare the propensity of managers from low creditor rights countries to omit dividend payments relative to managers from high creditor rights countries. The substitute hypothesis suggests that managers from low creditor rights countries will be more likely to omit dividend payments whenever debt repayments are in jeopardy. Second, we examine the interaction between creditor rights and credit quality. The manager of a high-credit-quality firm has less need to use restrictive dividend payouts as an alternative governance mechanism (i.e., as a substitute for weak creditor rights). We therefore expect that high credit quality will reduce the importance of creditor rights on dividend payouts. And third, we analyze the interaction be- tween creditor rights and free cash flows. We posit that the relation between creditor rights and dividend payouts will be stronger for firms with positive free cash flows.

\subsubsection{Creditor rights and dividend omissions}

In Table 6, we report the results for dividend omissions. We estimate a logit model with the same independent variables as described above in Table 2. However, instead of examining the propensity to pay dividends, we examine the propensity (or likelihood) to omit dividends. Our dependent variable, $O M I T$, equals one if a dividend-paying firm omits a dividend in the current year relative to the previous year. According to the substitute hypothesis, managers in coun- 
Table 5. Components of creditor rights and dividend amounts.

This table presents the pooled fixed-effect Tobit regression results. Sample period is 1990-2006. The dependent variable, DIV_TO_S, is the ratio of dividends (data 34) to sales (data 1). $R E_{t}$ is retained earnings (data 131) scaled by the book value of assets (data 89). $T E_{t}$ is the shareholders' equity (data 135) scaled by the book value of assets (data 89). $R O A_{t}$ is net income (data 32) scaled by the book value of assets (data 89). $S G R_{t}$ is the logarithmic sales growth computed as $\log \left(\right.$ data $1_{t} /$ data $\left.1_{t-1}\right)$. LOGSIZE $E_{t}$ is the natural logarithm of the book value of assets (data 89 ) in billions of $\$ \mathrm{US}$. $\mathrm{CASH}_{t}$ is the cash balance (data 61) scaled by the book value of assets (data 89). AD is shareholder rights index from Djankov, La Porta, Lopezde-Silanes, and Shleifer (2008). NO_AUTOSTAY equals one if there is no automatic stay on the secured creditors' assets, otherwise equals zero. SECURED_FIRST equals one if the secured creditors are given the priority of the claims during the bankruptcy. RESTRICT_REORG equals one if the management of the firm cannot file for reorganization unilaterally. MGMT_NOT_STAY equals one if either creditors or court can change the incumbent management during bankruptcy proceeding.

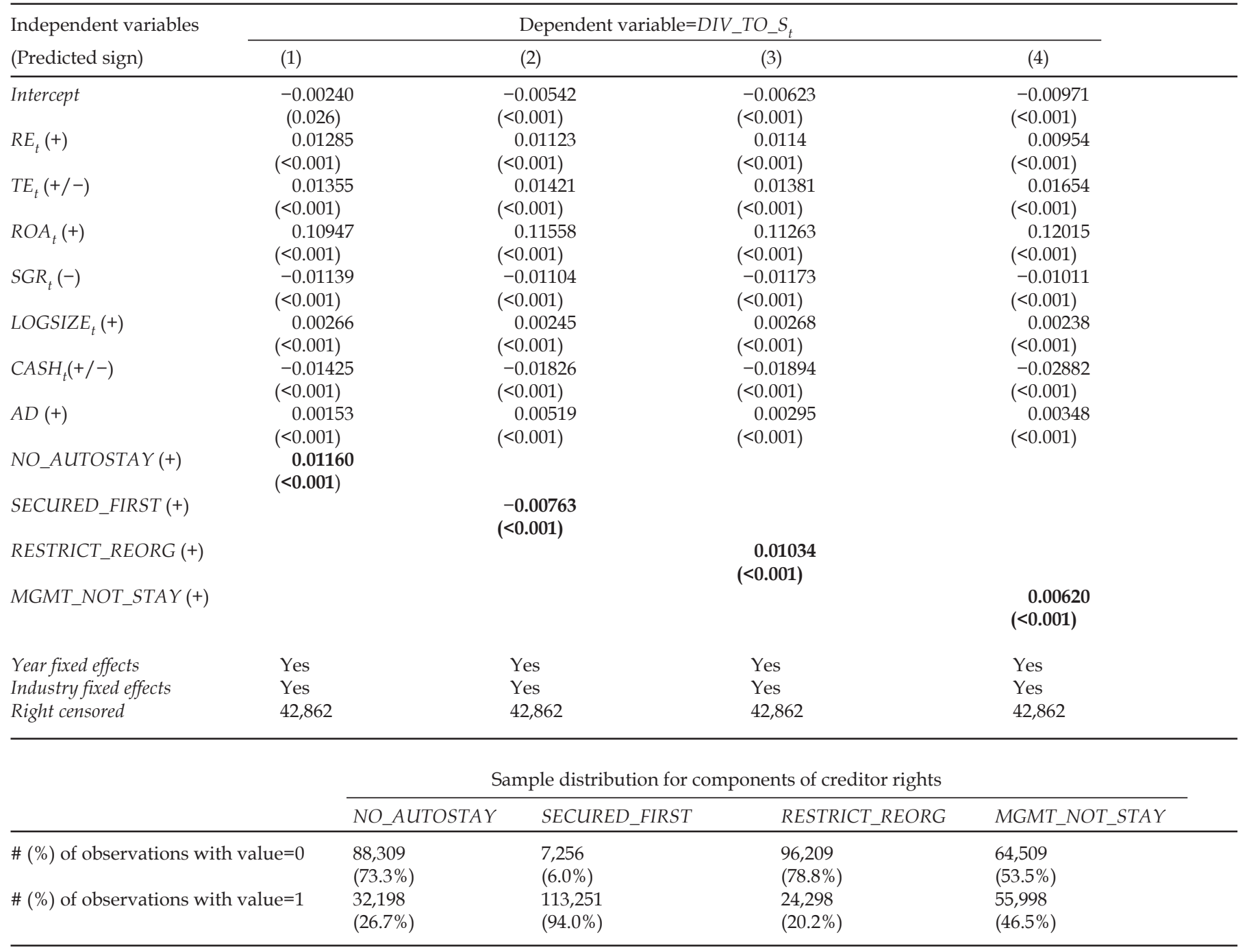

tries with weak creditor rights are more likely to omit dividend payments as a substitute governance mechanism. We therefore expect a negative relation between creditor rights and the likelihood of dividend omissions, all else equal.

In Model 1 the estimated coefficient for the creditor rights index $(-0.20486)$ is negative and significant, consistent with expectations. The likelihood that a manager omits a dividend payout decreases with creditor rights; that is, weak creditor rights increases the probability that a dividend-paying firm omits its dividend payment. In Model 2 we include firm-specific control variables, as well as a country-level shareholder rights index. The estimated coefficient for the creditor rights index $(-0.13564)$ is nega- tive and significant. The Pseudo- $R^{2}$ value increases from $0.70 \%$ in Model 1 without the control variables to $17.60 \%$ in Model 2 with the control variables. This increase suggests that our control variables have reasonably good explanatory power.

In Model 3 we add year fixed effects to Model 2 control variables, and in Model 4 we add industry fixed effects. The results from Models 3 and 4 confirm our findings from Models 1 and 2. Consistent with the substitute hypothesis, estimated coefficients for the creditor rights index $(-0.12984$ and -0.12739 , respectively) are negative and significant. Firms that operate in weak creditor rights environments are more likely to omit dividends because their managers 
are more sensitive to creditor concerns about debt repayment. These managers use a very restrictive dividend policy (i.e., omission) to reassure relatively unprotected creditors during times of uncertainty.

\subsubsection{Creditor rights, credit quality, and dividend payouts}

In Table 7, we report our results for the interaction between creditor rights and firm-level credit quality. The substitute hypothesis suggests that a high quality credit rating will reduce the need to use restrictive dividend payouts as an alternative governance mechanism. That is, the interaction between creditor rights and credit quality should be negative. In the first two columns of Table 7, we estimate a logit model with the propensity to pay, PAYER, as dependent variable. In the second two columns, we estimate a Tobit model with dividend amounts as the dependent variable.

Both regression types include our standard independent variables plus a credit quality dummy variable, $I N-$ $V G R A D E$, that equals one if the firm has an (estimated) investment grade credit rating and zero otherwise. We construct an investment grade credit rating proxy since credit ratings are not available for non-US firms in standard databases. First, we sample all non-regulated US firms with long-term debt between 1990 and 2006 from the Compustat database. Second, we fit a parsimonious logit regression with the dependent variable equal to one if the firm has an investment grade rating, and zero otherwise. The independent variables include the natural logarithm of firm size and earnings volatility (i.e., standard deviation of ROA estimated over the years $t, t-1, t-2$, and $t-3$ ). Our in-sample predictions show that the logit model has strong predictive power. ${ }^{19}$ Last, we apply the estimated coefficients to compute the probability of having an investment grade rating for each firm-year observation in the global sample. We set the investment grade dummy (INVGRADE) equal to one if the estimated probability of an investment grade rating exceeds $50 \%$, and zero otherwise. ${ }^{20}$

Our main variable of interest in Table 7 is the interaction between creditor rights and credit quality, $C R \times I N V G R A D E$. As hypothesized, the estimated coefficient for $C R \times I N V G R A D E(-0.32110)$ in Model 1 is negative and significant. We find a similarly negative and significant coefficient (-0.32402) in Model 2 after adding industry fixed affects to Model 1's year fixed effects. These negative interaction terms mean that high credit quality reduces the im- pact of creditor rights on the propensity to pay dividends. ${ }^{21}$ We perform a similar analysis for dividend amounts in Model 3 with year fixed effects and Model 4 with both year and industry fixed effects. The estimated $C R \times I N V G R A D E$ coefficients $(-0.00342$ and -0.00343 , respectively) are negative and significant. Consistent with expectations, credit quality acts as a mitigating factor in the creditor rights-dividend payout relation.

Table 6. Creditor rights and likelihood of dividend omissions.

This table presents the pooled fixed-effect logit regression results with firm-level clustered errors. Sample period is 1991-2006. The dependent variable, $\mathrm{OMIT}_{t}$, equals one if the firm omits a dividend payment (data 34 ) in the current year relative to the previous year. OMIT equals zero if the firm continues to pay dividends. $R E_{t}$ is retained earnings (data 131) scaled by the book value of assets (data 89). $T E_{t}$ is the shareholders' equity (data 135) scaled by the book value of assets (data 89). $R O A_{t}$ is net income (data 32) scaled by the book value of assets (data 89). SGR is the logarithmic sales growth computed as $\log$ (data $1_{t} /$ data $1_{t-1}$ ). LOGSIZE $_{t}$ is the natural logarithm of the book value of assets (data 89) in billions of $\$ U S$. $C A S H_{t}$ is the cash balance (data 61) scaled by the book value of assets (data 89). $C R_{t}$ and $A D$ are creditor and shareholder rights from Djankov, McLiesh, and Shleifer (2007) and Djankov, La Porta, Lopez-de-Silanes, and Shleifer (2008), respectively.

\begin{tabular}{|c|c|c|c|c|}
\hline \multirow{2}{*}{$\begin{array}{l}\text { Independent variables } \\
\text { (Predicted sign) }\end{array}$} & \multicolumn{4}{|c|}{ Dependent variable $=O M I T_{t}$} \\
\hline & 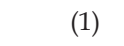 & (2) & (3) & (4) \\
\hline Intercept & $\begin{array}{l}-2.23395 \\
(<0.001)\end{array}$ & $\begin{array}{l}-0.53324 \\
(<0.001)\end{array}$ & $\begin{array}{l}-1.16947 \\
(<0.001)\end{array}$ & $\begin{array}{l}-1.49889 \\
(<0.001)\end{array}$ \\
\hline$R E_{t}(-)$ & & $\begin{array}{l}-1.56269 \\
(<0.001)\end{array}$ & $\begin{array}{l}-1.58144 \\
(<0.001)\end{array}$ & $\begin{array}{l}-1.51300 \\
(<0.001)\end{array}$ \\
\hline$T E_{t}(+/-)$ & & $\begin{array}{l}-0.77263 \\
(<0.001)\end{array}$ & $\begin{array}{l}-0.78279 \\
(<0.001)\end{array}$ & $\begin{array}{l}-0.86079 \\
(<0.001)\end{array}$ \\
\hline$R O A_{t}(-)$ & & $\begin{array}{l}-9.75816 \\
(<0.001)\end{array}$ & $\begin{array}{l}-9.52229 \\
(<0.001)\end{array}$ & $\begin{array}{l}-9.4945 \\
(<0.001)\end{array}$ \\
\hline$S G R_{t}(+)$ & & $\begin{array}{l}0.07434 \\
(0.429)\end{array}$ & $\begin{array}{l}0.11045 \\
(0.256)\end{array}$ & $\begin{array}{l}0.06988 \\
(0.474)\end{array}$ \\
\hline $\operatorname{LOGSIZE}_{t}(-)$ & & $\begin{array}{l}-0.34097 \\
(<0.001)\end{array}$ & $\begin{array}{l}-0.33156 \\
(<0.001)\end{array}$ & $\begin{array}{l}-0.33793 \\
(<0.001)\end{array}$ \\
\hline $\mathrm{CASH}_{t}(+/-)$ & & $\begin{array}{l}-1.64833 \\
(<0.001)\end{array}$ & $\begin{array}{l}-1.62740 \\
(<0.001)\end{array}$ & $\begin{array}{l}-1.59217 \\
(<0.001)\end{array}$ \\
\hline$A D(-)$ & & $\begin{array}{l}-0.4171 \\
(<0.001)\end{array}$ & $\begin{array}{l}-0.42224 \\
(<0.001)\end{array}$ & $\begin{array}{l}-0.42705 \\
(<0.001)\end{array}$ \\
\hline$C R_{t}(-)$ & $\begin{array}{l}-0.20486 \\
(<0.001)\end{array}$ & $\begin{array}{l}-0.13564 \\
(<0.001)\end{array}$ & $\begin{array}{l}-0.12984 \\
(<0.001)\end{array}$ & $\begin{array}{l}-0.12739 \\
(<0.001)\end{array}$ \\
\hline Year fixed effects & No & No & Yes & Yes \\
\hline Industry fixed effects & No & No & No & Yes \\
\hline Pseudo- $R^{2}$ & 0.007 & 0.176 & 0.188 & 0.190 \\
\hline
\end{tabular}

${ }^{19}$ More specifically, our statistical tests for predictive power include the following: Proportion concordant is $93.1 \%$; Somer's D is 0.869 (Somer's D ranges between -1.0 (worst predictive ability) and 1.0 (best predictive ability)); and $c$-statistic $=0.934$. The $c$-statistic represents the area under the receiver operating characteristic (ROC) curve (see Hanley and McNeil, 1982). A higher $c$-statistic implies stronger predictive power for the logistic regression. For example, a value of $c=0.5$ implies that the logit model randomly predicts the dependent variable (investment grade rating) whereas $c=1.0$ implies that the logit model perfectly discriminates the dependent variable.

${ }^{20}$ We test alternative credit quality proxies and find that our empirical results are robust to the choice of proxy. First, we add leverage, interest coverage, and profitability as additional independent variables and get very similar results. None of these models has a stronger predictive ability than the reported two-variable logit model. Second, since firms with long-term debt ratings are likely to have higher credit quality (Johnson, 2003) we proxy for credit risk using the presence of long-term debt ratings. More specifically, we fit a logit model where the dependent variable equals one if the firm has a Standard and Poor (S\&P) credit rating, and zero otherwise. Our results remain virtually unchanged. Last, we fit an ordered logit model where the dependent variable has four ordered ratings (A, B, C or D, and no rating) and find similar results as well.

${ }^{21}$ In Model 1, for example, the coefficient that measures the impact of creditor rights on the propensity to pay dividends when credit quality is low (i.e., INVGRADE $=0$ ) is 0.59523 . When credit quality is high (i.e., INVGRADE =1), the impact of creditor rights on the propensity to pay dividends is reduced to 0.27413 (i.e., $0.59523-0.32110$ ). The relation between creditor rights and dividend payouts remains positive, but its magnitude is reduced. 
Table 7. Effect of credit risk on the relation between creditor rights and dividends.

This table presents the pooled fixed-effect logit and Tobit regression results with firm-level clustered errors. Sample period is 1990-2006. The dependent variable is $P A Y E R_{t}$ in Models 1 and 2. The dependent variable is DIV_TO_S in Model 3 and 4 . PAYER equals one if the firm pays dividends (data $34>0$ ), otherwise equals zero. DIV_TO_S $S_{t}$ is the ratio of dividends (data 34) to sales (data 1 ). $R E_{t}$ is retained earnings (data 131) scaled by the book value of assets (data 89). $T E_{t}$ is the shareholders' equity (data 135) scaled by the book value of assets (data 89 ). $R O A_{t}$ is net

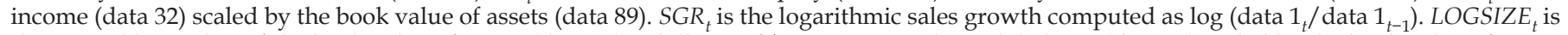
the natural logarithm of the book value of assets (data 89) in billions of $\$ \mathrm{US}$. $\mathrm{CASH}_{t}$ is the cash balance (data 61) scaled by the book value of assets (data 89). $C R_{t}$ and $A D$ are creditor and shareholder rights from Djankov, McLiesh, and Shleifer (2007) and Djankov, La Porta, Lopez-de-Silanes, and Shleifer (2008), respectively. INVGRADE $E_{t}$ equals one if the firm has an investment grade synthetic credit rating.

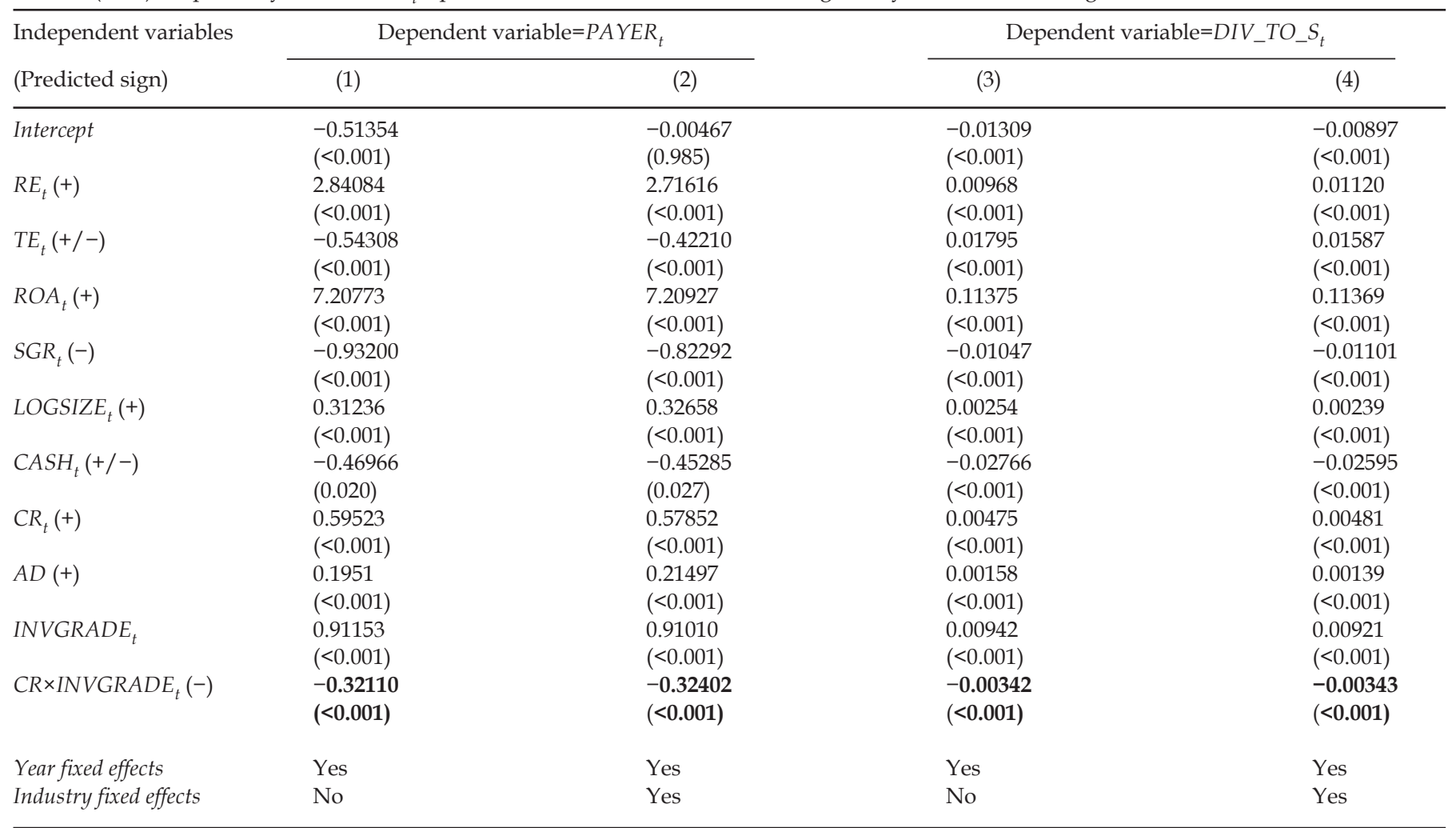

\subsubsection{Creditor rights, free cash flow, and dividend payouts}

In Table 8, we investigate the interaction between creditor rights and firm-level free cash flows. We follow the same format as in Table 7 by estimating two logit regressions for the propensity to pay dividends, and two Tobit regressions for dividend amounts. The first regression (i.e., Models 1 and 3 ) includes year fixed effects and the second regression includes both year and industry fixed effects. In addition to our standard control variables, we include a dummy variable for free cash flows, POS_FCF, which equals one if free cash flows are positive and zero otherwise. We define free cash flow as operating income (data 14) minus interest expense (data 15) minus income taxes (data 23) plus depreciation and amortization (data 11), all scaled by the book value of assets (data 89).

Our main variable of interest is the interaction between creditor rights and free cash flows, $C R \times P O S \_F C F$. In contrast to the mitigating effect of credit quality revealed in Table 7, we expect that positive free cash flows will exacerbate the relation between creditor rights and dividend pay- outs; that is, we posit a positive and significant coefficient for this interaction term.

As hypothesized, the estimated coefficient for $C R \times P O S$ FCF (0.28612) in Model 1 is positive and significant. We also find a positive and significant coefficient (0.29462) in Model 2 . The sign and significance levels of these interaction terms mean that positive free cash flows increase the impact of creditor rights on the propensity to pay dividends. ${ }^{22} \mathrm{We}$ perform a similar analysis for dividend amounts in Models 3 and 4 . The estimated CR $\times$ POS_FCF coefficients $(0.00200$ and 0.00188 , respectively) are positive and significant. Consistent with expectations, positive free cash flows increase the agency costs of debt and thereby magnify the relation between creditor rights and dividend payouts.

\subsection{Alternative explanations}

La Porta, Lopez-de-Silanes, Shleifer, and Vishny (1997) argue that weak creditor rights can impede financial market development. Other studies find that the cost of ex-

\footnotetext{
${ }^{22}$ In Model 1, for example, the coefficient that measures the impact of creditor rights on the propensity to pay dividends when free cash flows are non-positive (i.e., POS_FCF $=0$ ) is 0.34596 . When free cash flows are positive (i.e., POS_FCF =1), the impact of creditor rights on the propensity to pay dividends increases to 0.63208 (i.e., $0.34596+0.28612$ ). Free cash flows exacerbate the creditor rights-dividend payout relation.
} 
Table 8. Effect of free cash flow on the relation between creditor rights and dividends.

This table presents the pooled fixed-effect logit and Tobit regression results. Sample period is 1990-2006. The dependent variable is $P A Y E R_{t}$ in Models 1 and 2. The dependent variable is DIV_TO_S in Models 3 and 4 . PAYER equals one if the firm pays dividends (data 34>0), otherwise equals zero. DIV_TO_S $S_{t}$ is the ratio of dividends (data 34) to sales (data 1). $R E_{t}$ is retained earnings (data 131) scaled by the book value of assets (data 89). $T E_{t}$ is the shareholders' equity (data 135) scaled by the book value of assets (data 89). $R O A_{t}$ is net income (data 32) scaled by the book value of assets (data 89). SGR is the logarithmic sales growth computed as log (data $1_{t} /$ data $1_{t-1}$ ). LOGSIZE $E_{t}$ is the natural logarithm of the book value of assets (data 89) in billions of $\$ \mathrm{US}$. $C A S H_{t}$ is the cash balance (data 61) scaled by the book value of assets (data 89). $C R_{t}$ and $A D$ are creditor and shareholder rights from Djankov, McLiesh, and Shleifer (2007) and Djankov, La Porta, Lopez-de-Silanes, and Shleifer (2008), respectively. POS_FCF equals one if the firm has positive free cash flow. Free cash flow is defined as the operating income (data 14) minus interest expense (data 15) minus income taxes (data 23) plus depreciation and amortization (data 11) scaled by the book value of assets (data 89).

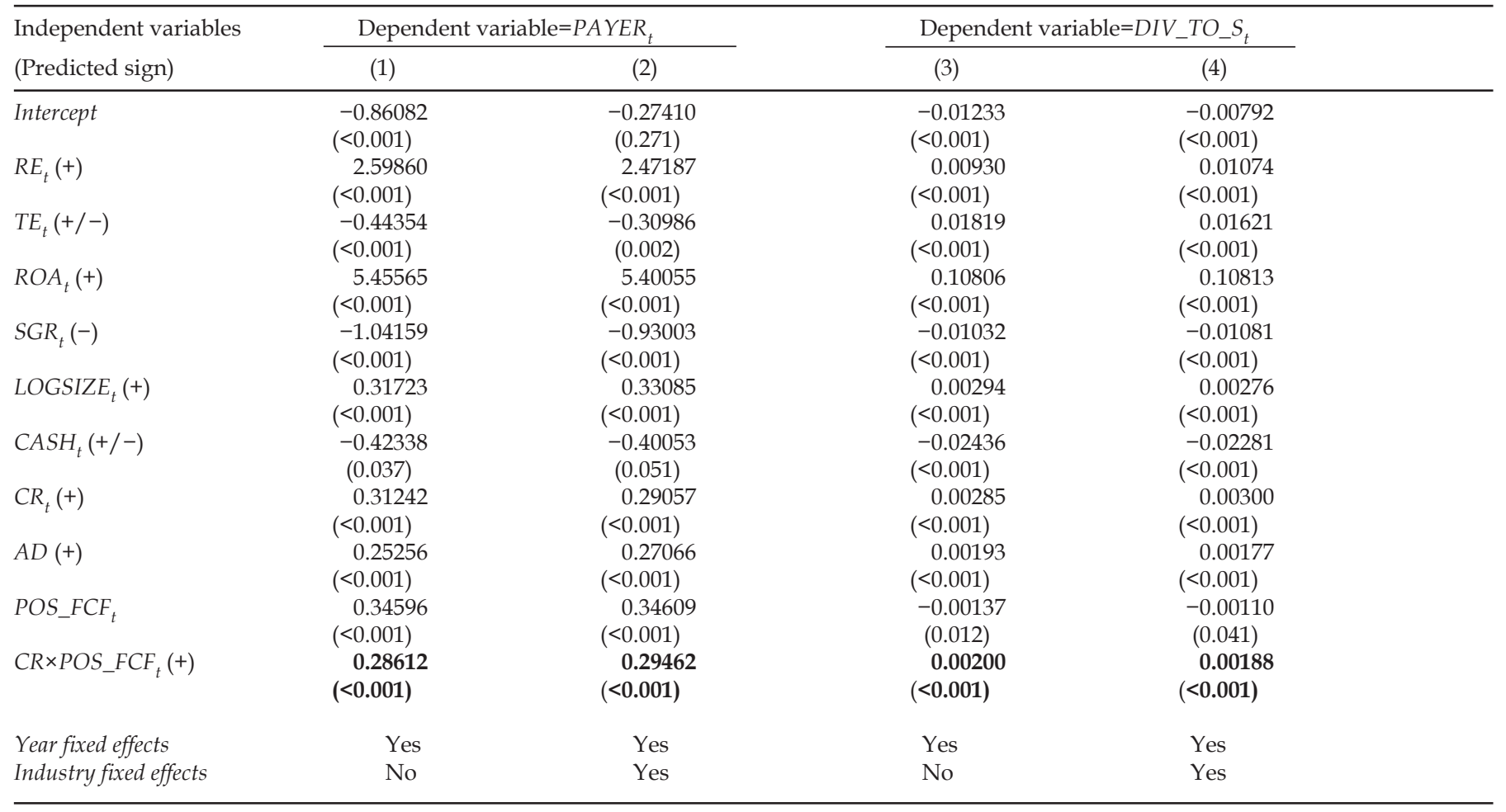

ternal financing is higher in financially underdeveloped countries (Rajan and Zingales, 1998; Demirguc-Kunt and Maksimovic, 1998). Khurana, Martin, and Pereira (2006) show that poor financial market development encourages internal cash savings in order to avoid expensive external financing. ${ }^{23}$ These results suggest an alternative connection between creditor rights and dividend policies: weak creditor rights lead to lower financial market development, and poor financial market development encourages internal cash retention over dividend payouts. We test the validity of this explanation by examining the impact of dividend changes on firm value. Under the alternative explanation, dividend increases should generate negative (or less positive) valuation effects in countries with weak creditor rights since larger dividend payouts increase the likelihood of expensive external financing. ${ }^{24}$
This competing hypothesis is similar to the tradeoff hypothesis developed in Pinkowitz, Stulz, and Williamson (2003). They attempt to distinguish between two competing hypotheses when explaining why firms in countries with weak institutions tend to hold more cash on their balance sheets. The agency cost hypothesis asserts that weak institutions allow insiders to extract more private benefits from these cash holdings. Since cash is the most liquid asset, it can easily be stolen in countries with weak institutions. ${ }^{25}$ In contrast, the tradeoff hypothesis posits that firms in countries with weak institutions hold more cash because external financing is relatively expensive. Pinkowitz, Stulz, and Williamson (2003) find support for the agency hypothesis by showing that the market value of a dollar held as cash is only 65 cents in countries with weak institutions. They reject the tradeoff hypothesis since holding cash does not appear to be value enhancing.

${ }^{23}$ In a related study, Love (2003) shows that financial underdevelopment increases the positive relation between internal funds and investments due to strong financial constraints.

${ }^{24}$ This argument implicitly assumes that firms do not increase dividend payouts as part of a signaling strategy (i.e., using dividends as a costly and therefore credible signal of future profitability). Although recent research suggests that dividends are not used to signal future profitability (Grullon, Michaely, Benartzi, and Thaler 2005), the effectiveness of this test will be reduced by the extent to which firms use dividends to signal future profitability.

${ }^{25}$ Johnson, La Porta, Lopez-de-Silanes, and Shleifer (2000) highlight an interesting Belgian case that shows just how easy it can be to steal cash from a firm. Also supporting this view, Dittmar, Mahrt-Smith, and Servaes (2003) find a negative relation between shareholder rights and cash holdings. 
In this section, we test a dividend payout version of the tradeoff hypothesis by examining whether dividend reductions (increases) are value enhancing (destroying) for firms in countries with poor creditor rights. Following previous studies (Pinkowitz, Stulz, and Williamson, 2003; Dittmar, Mahrt-Smith, and Servaes, 2006), we use Fama and French (1998) empirical specification to model the market value of equity. The full model is given as follows:

$$
\begin{aligned}
\frac{V_{t}}{A_{t}}= & \alpha_{0}+\alpha_{1} \frac{E_{t}}{A_{t}}+\alpha_{2} \frac{d E_{t}}{A_{t}}+\alpha_{3} \frac{d E_{t+2}}{A_{t}}+\alpha_{4} \frac{d A_{t}}{A_{t}} \\
+ & \alpha_{5} \frac{A_{t+2}}{A_{t}}+\alpha_{6} \frac{R D_{t}}{A_{t}}+\alpha_{7} \frac{d R D_{t}}{A_{t}}+\alpha_{8} \frac{d R D V_{t+2}}{A_{t}}+\alpha_{9} \frac{I_{t}}{A_{t}} \\
& +\alpha_{10} \frac{d I_{t}}{A_{t}}+\alpha_{11} \frac{d I_{t+2}}{A_{t}}+\alpha_{12} \frac{D_{t}}{A_{t}}+\alpha_{13} \frac{d D_{t}}{A_{t}}+\alpha_{14} \frac{d D_{t+2}}{A_{t}} \\
& +\alpha_{15} \frac{d V_{t+2}}{A_{t}}+\alpha_{16} C R \frac{d D_{t+2}}{A_{t}}+\eta \text { CIVIL } \\
& +\sum_{\text {ind }=1}^{16} \gamma_{\text {ind }} 1_{\text {ind }}+\varepsilon_{t}
\end{aligned}
$$

All of the variables are scaled by the book value of assets $\left(A_{t}\right.$, data 89$)$ to account for heteroskedasticity. The dependent variable is the market value of equity $\left(V_{t}\right)$ scaled by book value of assets. ${ }^{26}$ The independent variables include earnings $\left(E_{t}\right)$, interest expense $\left(I_{t}\right)$, research and development $\left(R D_{t}\right)$, and dividends $\left(D_{t}\right)$, all scaled by $A_{t}$. $E_{t}$ equals net income (data 32) plus interest expense (data 15) plus deferred taxes (data 25); $R D_{t}$ equals research and development expense (data 52); $I_{t}$ equals interest expense (data 15); and $D_{t}$ equals the total amount of dividends (data 34). $d X_{t}$ is the difference between $X_{t}$ and $X_{t-2}$ for variable $X$, and $d X_{t}$ +2 is the difference between $X_{t+2}$ and $X_{t}$. We also include a civil law dummy in the regression since La Porta, Lopezde-Silanes, Shleifer, and Vishny (2002) show that valuations are lower in civil law counties. The main variable of interest is the interaction term between creditor rights and the change in dividends $\left(C R\left(d D_{t+2} / A_{t}\right)\right)$. The coefficient of this variable, $\alpha_{16}$, is predicted to be positive according to the (competing) tradeoff hypothesis.

To estimate regression Model 3, we first delete any firmyears that do not have data in the required fields. This process reduces our sample size from 120,507 firm-year observations to 67,331 firm-year observations. We check for biases in the reduced sample by comparing its distributions across years, industries, and countries to the full sample distributions in Panels A, B, and C of Table 9. Overall, the reduced sample appears to be fairly representative of the full sample across years, industries, and countries.

In Table 10, we report Fama-MacBeth (1973) estimations for variations on regression Model 3. Due to space limitations, we report only the coefficient estimates for the main variable of interest, the interaction term $\left(\alpha_{16}\right)$. All other coefficient estimates are consistent with prior studies. The market value of equity $\left(V_{t} / A_{t}\right)$ is positively related to earnings $\left(E_{t} / A_{t^{\prime}} d E_{t+2} / A_{t}, d E_{t+2} / A_{t}\right)$, changes in the book value of assets $\left(d A_{t} / A_{t}, d A_{t+2} / A_{t}\right)$, research and development $\left(R D_{t} /\right.$ $\left.A_{t^{\prime}} d R D_{t} / A_{t^{\prime}} d R D_{t+2} / A_{t}\right)$, and dividends $\left(D_{t} / A_{t^{\prime}} d D_{t} / A_{t^{\prime}}\right.$ $\left.d D_{t+2} / A_{t}\right)$; it is negatively related to interest expense $\left(I_{t} / A_{t^{\prime}}\right.$ $\left.d I_{t} / A_{t}, d I_{t+2} / A_{t}\right)$, future changes in market value of equity $\left(d V_{t+2} / A_{t}\right)$, and the civil law dummy (CIVIL).

The first row of Table 10 presents the mean $\alpha_{16}$ coefficient estimate across 13 annual regressions. These mean values are negative in each model specification, a finding that is inconsistent with the dividend tradeoff hypothesis. The second row shows that serial correlation adjusted $t$ statistics are all insignificant at conventional levels. ${ }^{27}$ The last four rows provide the annual distributions of $\alpha_{16}$ coefficients. For example, in Model 1, two (seven) of the 13 annual $\alpha_{16}$ estimates are negative and significant (insignificant); two (two) of the 13 annual $\alpha_{16}$ estimates are positive and significant (insignificant). Overall, we find no evidence in support of the (alternative) dividend tradeoff hypothesis. $^{28}$

\subsection{Robustness tests: control variables, subsamples, and model specifications}

In this section, we subject our previous results to a number of robustness tests. In Section 3.6.1, we control for other institutional features including legal origin, rule of law, disclosure quality, and financial development. In Section 3.6.2, we allow for the possibility of time-varying firm characteristics. In Section 3.6.3, we test whether our results are driven by the large presence of US, Japanese, and UK firms. We also test for confounding effects from countries adversely affected by the Asian currency crisis. In Section 3.6.4, we re-estimate our results using Fama and MacBeth (1973) approach. And in Section 3.6.5, we re-estimate all regression equations using country means. Overall, we attempt to ensure that the positive and strong relation between creditor rights and dividends is not due to sample selection biases or empirical misspecifications.

\subsubsection{Country-specific variables}

In this subsection, we test whether previous results are driven by omitted institutional features. We consider legal origin, rule of law, accounting standards, and financial development. ${ }^{29}$ La Porta, Lopez-de-Silanes, Shleifer,

\footnotetext{
${ }^{26}$ Our main findings and conclusions are unchanged using sales or the book value of equity as the scaling variable.

${ }^{27}$ We adjust the $t$-statistics for serial correlation by dividing into two. Since the sample size is 13 , this is a conservative adjustment which favors finding significant results. An adjustment factor of two implies a mild serial correlation of 0.112. For details of serial correlation adjustment see Petersen (2006).

${ }^{28}$ We replicate Table 10 results for each component of the creditor rights index and find no evidence for the competing hypothesis in any of the results.

${ }^{29}$ The rule of law index is from Kaufmann, Kraay, and Mastruzzi (2003) and measures the law and order tradition in a country. Accounting standards include two dummy variables. Low accounting standards dummy equals one if the disclosure score of the firm's country is in the bottom global quartile, otherwise zero. High accounting standards dummy equals one if the disclosure score of the firm's country is in the top global quartile, otherwise zero. Accounting disclosure scores are from Center for International Financial Analysis and Research (CIFAR, 1995). Capital market development is proxied by two indexes that measure the development of stock markets and financial intermediaries (DemirgucKunt and Levine, 1996). The stock market development index is the average of standardized values of market capitalizations to GDP, total value traded to GDP, and total value traded to market capitalization. The financial intermediary development index is the average of standardized values of liquid liabilities to GDP, and domestic credit for private firms to GDP.
} 
Table 9. Reduced and full sample comparison.

This table compares the subsample distribution to the original sample across years, industries, and countries. Panel A compares sample sizes between the full sample and the reduced sample. Panel B provides industry comparisons between the full sample and the reduced sample. Panel C compares the full and reduced sample distributions across countries.

Panel A: Annual number of observations

\begin{tabular}{|c|c|c|c|c|c|c|c|}
\hline Year & $\begin{array}{c}N \\
\text { (Subsample) }\end{array}$ & $\begin{array}{c}\mathrm{N} \\
\text { (Main sample) }\end{array}$ & Proportion (\%) & Year & $\begin{array}{c}N \\
\text { (Subsample) }\end{array}$ & $\begin{array}{c}N \\
\text { (Main sample) }\end{array}$ & Proportion (\%) \\
\hline 1992 & 3,103 & 4,265 & 72.8 & 1999 & 6,695 & 9,490 & 70.5 \\
\hline 1993 & 3,315 & 4,622 & 71.7 & 2000 & 6,831 & 9,677 & 70.6 \\
\hline 1994 & 3,819 & 5,387 & 70.9 & 2001 & 6,910 & 9,804 & 70.5 \\
\hline 1995 & 4,218 & 6,072 & 69.5 & 2002 & 6,026 & 9,751 & 61.8 \\
\hline 1996 & 4,710 & 6,670 & 70.6 & 2003 & 5,675 & 9,529 & 59.6 \\
\hline 1997 & 5,140 & 7,779 & 66.1 & 2004 & 4,777 & 7,799 & 61.3 \\
\hline 1998 & 6,112 & 9,292 & 65.8 & & & & \\
\hline
\end{tabular}

Panel B: Sample distribution across industries

\begin{tabular}{lrr}
\hline NAICS industry definition & $\begin{array}{r}\text { \% Observations } \\
\text { (Subsample) }\end{array}$ & $\begin{array}{r}\text { \% Observations } \\
\text { (Main sample) }\end{array}$ \\
\hline Agriculture, forestry, fishing, and hunting & 0.9 & 0.9 \\
Mining & 3.7 & 4.0 \\
Construction & 4.8 & 4.5 \\
Manufacturing & 55.2 & 53.7 \\
Wholesale trade & 6.5 & 6.1 \\
Retail trade & 6.3 & 6.3 \\
Transportation and warehousing & 4.5 & 4.2 \\
Information & 5.9 & 6.9 \\
Real estate and rental and leasing & 1.5 & 1.5 \\
Professional, scientific, and technical services & 4.1 & 4.9 \\
Management of companies and enterprises & 0.1 & 0.1 \\
Administrative and support and waste management & 1.8 & 1.8 \\
Educational services & 0.3 & 0.3 \\
Health care and social assistance & 1.3 & 1.3 \\
Arts, entertainment, and recreation & 0.8 & 0.8 \\
Accommodation and food services & 2.2 & 2.3 \\
Other services (except public administration) & 0.4 & 0.4 \\
Total & 100.0 & 100.0
\end{tabular}

Panel C: Sample distribution across countries

\begin{tabular}{|c|c|c|}
\hline Country & $\begin{array}{r}\text { \% Observations } \\
\text { (Subsample) }\end{array}$ & $\begin{array}{r}\% \text { Observations } \\
\text { (Main sample) }\end{array}$ \\
\hline \multicolumn{3}{|c|}{ Common law countries } \\
\hline Australia & 2.302 & 2.290 \\
\hline Ghana & 0.000 & 0.003 \\
\hline Hong Kong & 0.918 & 0.817 \\
\hline India & 0.122 & 0.418 \\
\hline Kenya & 0.007 & 0.008 \\
\hline Malaysia & 3.848 & 4.084 \\
\hline New Zealand & 0.267 & 0.303 \\
\hline Pakistan & 0.088 & 0.131 \\
\hline Singapore & 1.953 & 2.211 \\
\hline South Africa & 0.602 & 0.638 \\
\hline \multicolumn{3}{|l|}{ Civil law countries } \\
\hline Argentina & 0.059 & 0.115 \\
\hline Austria & 0.465 & 0.474 \\
\hline Belgium & 0.472 & 0.592 \\
\hline
\end{tabular}


Table 9 (continued).

Panel C: Sample distribution across countries

\begin{tabular}{|c|c|c|}
\hline Country & $\begin{array}{c}\text { \% Observations } \\
\text { (Subsample) }\end{array}$ & $\begin{array}{r}\text { \% Observations } \\
\text { (Main sample) }\end{array}$ \\
\hline China & 0.982 & 2.526 \\
\hline Croatia & 0.006 & 0.010 \\
\hline Denmark & 0.885 & 1.056 \\
\hline Egypt, Arab Republic & 0.006 & 0.016 \\
\hline Finland & 0.869 & 0.861 \\
\hline Hungary & 0.049 & 0.075 \\
\hline Indonesia & 1.046 & 1.080 \\
\hline Italy & 0.910 & 1.084 \\
\hline Japan & 24.296 & 19.123 \\
\hline Jordan & 0.006 & 0.011 \\
\hline Republic of Korea & 0.683 & 0.960 \\
\hline Peru & 0.037 & 0.060 \\
\hline Philippines & 0.208 & 0.363 \\
\hline Poland & 0.052 & 0.104 \\
\hline Portugal & 0.183 & 0.250 \\
\hline Romania & 0.000 & 0.004 \\
\hline Russian Federation & 0.033 & 0.068 \\
\hline Slovak Republic & 0.016 & 0.021 \\
\hline Spain & 0.814 & 0.831 \\
\hline Sweden & 1.408 & 1.548 \\
\hline Switzerland & 1.319 & 1.374 \\
\hline Taiwan, China & 0.391 & 0.496 \\
\hline Turkey & 0.095 & 0.139 \\
\hline
\end{tabular}

and Vishny (2000) show that firms from civil law countries have lower payout ratios than firms from common law countries. Brockman and Unlu (2008) show a significant relation between accounting disclosure quality and dividend payouts. Finally, a lack of financial development might encourage firms to accumulate more internal funds which, in turn, could discourage dividend payments.

The first four rows in Panel A of Table 11 report the coefficient estimates for $C R$ after adding a civil law dummy, rule of law, accounting standards, and financial development measures to the right-hand side of a baseline model (e.g., Models 3 and 4 of Table 2 and Table 3). The last row reports coefficient estimates for the specifications where all controls are included jointly. Overall, the results are very robust. In each case, the positive relation between creditor rights and dividends (both in terms of likelihood and amounts) is positive and statistically significant. It is unlikely that previous results are driven by omitted institutional features. ${ }^{30}$

\subsubsection{Time-varying firm characteristics}

In this subsection, we re-estimate the empirical specifications in Panel A by using the annual decile ranks of firm- specific variables (instead of the variable itself). This helps control for possible confounding effects from time-varying firm characteristics on the coefficient estimates. As shown in Panel B of Table 11, the CR coefficient estimates remain positive and significant.

\subsubsection{Potential sample biases}

This subsection addresses two sample selection issues: (1) the uneven distribution of observations among countries and (2) the occurrence of the East Asian currency crisis during our sample period. We create five subsamples and report the results in Panel $\mathrm{C}$ of Table 11. The first subsample excludes US firms, reducing the sample size by $32.1 \%$. The second and third subsamples exclude Japanese and UK firms, reducing the sample size by $19.1 \%$ and $8.6 \%$, respectively. The fourth subsample excludes firms from Indonesia, Malaysia, the Philippines, and Thailand, which account for $6.8 \%$ of our total sample. Finally, we exclude all of the countries mentioned above. The results in Panel $\mathrm{C}$ of Table 11 show that the positive and significant relation between creditor rights and dividend payouts is robust with respect to all of our subsamples.

${ }^{30}$ As an additional robustness test, we re-run these model specifications after deleting observations from countries in the lowest quartile of stock market development and the lowest quartile of financial intermediation (as defined in Demirguc-Kunt and Levine, 1996). Our conclusions are unchanged. 
Table 10. Creditor rights and dividends valuations.

This table shows the relation between $C R$ and the valuation impact increase in dividends. Sample period is restricted to 1992-2004 since variables require two-year lead/lag values. Each specification shown below is estimated annually consistent with the Fama and MacBeth (1973) technique. The variables with the coefficients $\alpha_{1}$ to $\alpha_{15}$ are adopted from Fama and French (1998). Due to space limitations estimation results are only shown for the main coefficient of interest $\left(\alpha_{16}\right)$.

$$
\begin{aligned}
& \text { [1] } \frac{V_{t}}{A_{t}}=\alpha_{0}+\alpha_{1} \frac{E_{t}}{A_{t}}+\alpha_{2} \frac{d E_{t}}{A_{t}}+\alpha_{3} \frac{d E_{t+2}}{A_{t}}+\alpha_{4} \frac{d A_{t}}{A_{t}}+\alpha_{5} \frac{d A_{t+2}}{A_{t}}+\alpha_{6} \frac{R D_{t}}{A_{t}}+\alpha_{7} \frac{d R D_{t}}{A_{t}}+\alpha_{8} \frac{d R D_{t+2}}{A_{t}}+\alpha_{9} \frac{I_{t}}{A_{t}} \\
& +\alpha_{10} \frac{d I_{t}}{A_{t}}+\alpha_{11} \frac{d I_{t+2}}{A_{t}}+\alpha_{12} \frac{D_{t}}{A_{t}}+\alpha_{13} \frac{d D_{t}}{A_{t}}+\alpha_{14} \frac{d D_{t+2}}{A_{t}}+\alpha_{15} \frac{d V_{t+2}}{A_{t}}+\alpha_{16} C R_{t} \frac{d D_{t+2}}{A_{t}}+\varepsilon_{t} \\
& \text { [2] } \frac{V_{t}}{A_{t}}=\alpha_{0}+\alpha_{1} \frac{E_{t}}{A_{t}}+\alpha_{2} \frac{d E_{t}}{A_{t}}+\alpha_{3} \frac{d E_{t+2}}{A_{t}}+\alpha_{4} \frac{d A_{t}}{A_{t}}+\alpha_{5} \frac{d A_{t+2}}{A_{t}}+\alpha_{6} \frac{R D_{t}}{A_{t}}+\alpha_{7} \frac{d R D_{t}}{A_{t}}+\alpha_{8} \frac{d R D_{t+2}}{A_{t}} \\
& +\alpha_{9} \frac{I_{t}}{A_{t}}+\alpha_{10} \frac{d I_{t}}{A_{t}}+\alpha_{11} \frac{d I_{t+2}}{A_{t}}+\alpha_{12} \frac{D_{t}}{A_{t}}+\alpha_{13} \frac{d D_{t}}{A_{t}}+\alpha_{14} \frac{d D_{t+2}}{A_{t}}+\alpha_{15} \frac{d V_{t+2}}{A_{t}} \\
& +\alpha_{16} C R_{t} \frac{d D_{t+2}}{A_{t}}+\sum_{i n d=1}^{16} \gamma \text { ind }{ }^{1} \text { ind }+\varepsilon_{t} \\
& \text { [3] } \frac{V_{t}}{A_{t}}=\alpha_{0}+\alpha_{1} \frac{E_{t}}{A_{t}}+\alpha_{2} \frac{d E_{t}}{A_{t}}+\alpha_{3} \frac{d E_{t+2}}{A_{t}}+\alpha_{4} \frac{d A_{t}}{A_{t}}+\alpha_{5} \frac{d A_{t+2}}{A_{t}}+\alpha_{6} \frac{R D_{t}}{A_{t}}+\alpha_{7} \frac{d R D_{t}}{A_{t}}+\alpha_{8} \frac{d R D_{t+2}}{A_{t}} \\
& +\alpha_{9} \frac{I_{t}}{A_{t}}+\alpha_{10} \frac{d I_{t}}{A_{t}}+\alpha_{11} \frac{d I_{t+2}}{A_{t}}+\alpha_{12} \frac{D_{t}}{A_{t}}+\alpha_{13} \frac{d D_{t}}{A_{t}}+\alpha_{14} \frac{d D_{t+2}}{A_{t}} \\
& +\alpha_{15} \frac{d V_{t+2}}{A_{t}}+\alpha_{16} C R_{t} \frac{d D_{t+2}}{A_{t}}+\eta \text { CIVIL } \varepsilon_{t} \\
& \text { [4] } \frac{V_{t}}{A_{t}}=\alpha_{0}+\alpha_{1} \frac{E_{t}}{A_{t}}+\alpha_{2} \frac{d E_{t}}{A_{t}}+\alpha_{3} \frac{d E_{t+2}}{A_{t}}+\alpha_{4} \frac{d A_{t}}{A_{t}}+\alpha_{5} \frac{d A_{t+2}}{A_{t}}+\alpha_{6} \frac{R D_{t}}{A_{t}}+\alpha_{7} \frac{d R D_{t}}{A_{t}} \\
& +\alpha_{8} \frac{d R D_{t+2}}{A_{t}}+\alpha_{9} \frac{I_{t}}{A_{t}}+\alpha_{10} \frac{d I_{t}}{A_{t}}+\alpha_{11} \frac{d I_{t+2}}{A_{t}}+\alpha_{12} \frac{D_{t}}{A_{t}}+\alpha_{13} \frac{d D_{t}}{A_{t}}+\alpha_{14} \frac{d D_{t+2}}{A_{t}} \\
& +\alpha_{15} \frac{d V_{t+2}}{A_{t}}+\alpha_{16} C R_{t} \frac{d D_{t+2}}{A_{t}}+\eta \text { CIVIL }+\sum_{\text {ind }=1}^{16} \gamma_{\text {ind }}{ }^{1} \text { ind }+\varepsilon_{t}
\end{aligned}
$$

$V_{t}$ is the market value of equity computed as price per share (Compustat Issues file item 3 ) times number of shares outstanding (Compustat Issues file item 13) times the exchange rate (where necessary). $A_{t}$ is the book value of assets (data 89). $E_{t}$ is net income (data 32 ) plus interest expense (data 15) plus deferred taxes (data 25, where available). $R D_{t}$ is research and development expense (data 52 , where available). $I_{t}$ is the interest expense (data 15). $D_{t}$ is dividends (data 34). $d X_{t}$ implies the difference between $X_{t}$ and $X_{t-2}$ for variable $X . d X_{t+2}$ implies the difference between $X_{t+2}$ and $X_{t}$ for variable $X . \varepsilon$ is the error term. $C R$ is creditor rights index. CIVIL equals one if the firm is incorporated in a civil law country, otherwise equals zero.

\begin{tabular}{llccc}
\hline Summary of results & $\begin{array}{l}\alpha_{16} \\
\text { (Model 1) }\end{array}$ & $\begin{array}{l}\alpha_{16} \alpha_{16} \\
\text { (Model 2) }\end{array}$ & $\begin{array}{l}\alpha_{16} \\
\text { (Model 3) }\end{array}$ & (Model 4) \\
\hline Mean of estimated $\alpha_{16}$ & -0.09547 & -0.31117 & -0.17674 & -0.37849 \\
Adjusted $t$-statistic for the mean & $(-0.11337)$ & $(-0.42423)$ & $(-0.20891)$ & $(-0.51309)$ \\
Number of positive and significant ${ }^{a}$ estimates & 2 & 2 & 2 & 2 \\
Number of positive and insignificant estimates & 2 & 2 & 2 & 2 \\
Number of negative and significant ${ }^{\mathrm{a}}$ estimates & 2 & 2 & 4 & 4 \\
Number of negative and insignificant estimates & 7 & 7 & 5 & 5 \\
\hline
\end{tabular}

a At $10 \%$ level or less.

\subsubsection{Fama and Macbeth (1973) regressions}

In Panel D of Table 11, we report the CR coefficient estimates using Fama and MacBeth (1973) method. The first two rows report average coefficient estimates and corresponding $p$-values. Consistent with prior analyses, we find that the average of 17 (annual) coefficient estimates is positive, significant, and similar in magnitude to that of the pooled regressions. The distribution of the annual coefficients also reveals that our statistical significance is not driven by serial correlation. As shown in the bottom four rows, all of the $C R$ coefficient estimates are positive and significant at the 10\% level. Overall, the Fama and MacBeth (1973) results confirm our earlier pooled cross-sectional time-series findings. 
Table 11. Additional analyses.

Panel A reports the coefficient for CR in Models 3 and 4 of Table 2 and Table 3 after adding civil law dummy, accounting standards, rule of law, and capital market development indexes as additional controls. Rule of law index is from Kaufmann, Kraay, and Mastruzzi (2003) and measures the extent of law and order tradition in a country. Accounting standards include two dummy variables. Low accounting standards dummy equals one if the disclosure score of the firm's country is in the bottom global quartile, otherwise zero. High accounting standards dummy equals one if the disclosure score of the firm's country is in the top global quartile, otherwise equals zero. Country-level disclosure scores are from the Center for International Financial Analysis and Research (CIFAR, 1995). Capital market development is proxied by two indexes that measure the development of stock market and financial intermediaries. These measures are computed following Demirguc-Kunt and Levine (1996). Stock market development index is the average of standardized values of market capitalization to GDP, total value traded to GDP, and total value traded to market capitalization ratios. Financial intermediary development index is the average of standardized values of liquid liabilities to GDP and domestic credit for private firms to GDP ratios. Panel B reports the coefficient estimates for CR for the same specifications in Panel A after adjusting for the time-varying firm-characteristics/dividend relation. Each firm-specific independent variable is assigned a decile rank annually and these decile ranks are used in the regressions instead of the variable. Panel $\mathrm{C}$ reports the coefficient estimates for $C R$ for various subsamples. Panel $\mathrm{D}$ reports the distribution of $C R$ based on the Fama and MacBeth (1973) technique. Panel E reports the coefficient estimates for CR using country means with country-level error clustering and year fixed effects.

\section{Panel A: Coefficient estimates and $p$-values for $C R$}

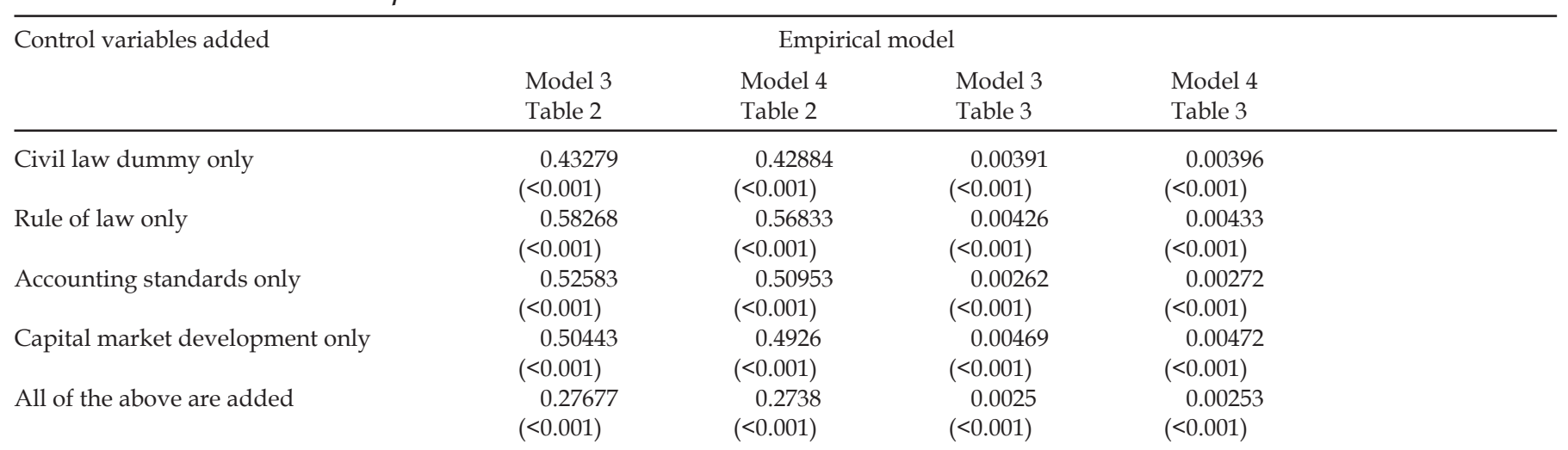

Panel B: Coefficient estimates and $p$-values for $C R$ controlling for time-varying firm-characteristics/ dividend relation.

\begin{tabular}{|c|c|c|c|c|}
\hline \multirow[t]{2}{*}{ Control variables added } & \multicolumn{4}{|c|}{ Empirical model (with annual decile ranks) } \\
\hline & $\begin{array}{r}\text { Model } 3 \\
\text { Table } 2 \\
\end{array}$ & $\begin{array}{r}\text { Model } 4 \\
\text { Table } 2 \\
\end{array}$ & $\begin{array}{r}\text { Model } 3 \\
\text { Table } 3 \\
\end{array}$ & $\begin{array}{r}\text { Model } 4 \\
\text { Table } 3 \\
\end{array}$ \\
\hline Rule of law only & $\begin{array}{c}0.00464 \\
(<0.001)\end{array}$ & $\begin{aligned} & 0.00468 \\
&(<0.001)\end{aligned}$ & $\begin{array}{c}0.00464 \\
(<0.001)\end{array}$ & $\begin{array}{c}0.00468 \\
(<0.001)\end{array}$ \\
\hline Capital market development only & $\begin{array}{l}0.00480 \\
(<0.001)\end{array}$ & $\begin{array}{l}0.00481 \\
(<0.001)\end{array}$ & $\begin{array}{c}0.00480 \\
(<0.001)\end{array}$ & $\begin{array}{c}0.00481 \\
(<0.001)\end{array}$ \\
\hline All of the above are added & $\begin{array}{l}0.00250 \\
(<0.001)\end{array}$ & $\begin{array}{c}0.00254 \\
(<0.001)\end{array}$ & $\begin{array}{l}0.00250 \\
(<0.001)\end{array}$ & $\begin{array}{c}0.00254 \\
(<0.001)\end{array}$ \\
\hline
\end{tabular}

Panel C: Coefficient estimates and $p$-values for $C R$ for sample selection biases

\begin{tabular}{|c|c|c|c|c|}
\hline \multirow[t]{2}{*}{ Control variables added } & \multicolumn{4}{|c|}{ Empirical model } \\
\hline & $\begin{array}{r}\text { Model } 3 \\
\text { Table } 2 \\
\end{array}$ & $\begin{array}{r}\text { Model } 4 \\
\text { Table } 2 \\
\end{array}$ & $\begin{array}{r}\text { Model } 3 \\
\text { Table } 3 \\
\end{array}$ & $\begin{array}{r}\text { Model } 4 \\
\text { Table } 3 \\
\end{array}$ \\
\hline Only Japanese firms are excluded & $\begin{array}{c}0.61394 \\
(<0.001)\end{array}$ & $\begin{array}{l}0.60022 \\
(<0.001)\end{array}$ & $\begin{aligned} & 0.00593 \\
&(<0.001)\end{aligned}$ & $\begin{array}{c}0.00594 \\
(<0.001)\end{array}$ \\
\hline Only Indonesian, Malaysian, Philippine, and Thai firms are excluded & $\begin{array}{c}0.58961 \\
(<0.001)\end{array}$ & $\begin{array}{l}0.57178 \\
(<0.001)\end{array}$ & $\begin{array}{c}0.00431 \\
(<0.001)\end{array}$ & $\begin{array}{l}0.00436 \\
(<0.001)\end{array}$ \\
\hline All of the above are excluded & $\begin{aligned} & 0.21788 \\
&(<0.001)\end{aligned}$ & $\begin{array}{c}0.19179 \\
(<0.001)\end{array}$ & $\begin{array}{l}0.00180 \\
(<0.001)\end{array}$ & $\begin{array}{l}0.00173 \\
(<0.001)\end{array}$ \\
\hline
\end{tabular}


Table 11 (continued).

Panel D: Estimation results for $C R$ based on Fama and MacBeth (1973)

\begin{tabular}{|c|c|c|c|c|}
\hline \multirow[t]{2}{*}{ Statistics for $C R$ for 17 annual regressions } & \multicolumn{4}{|c|}{ Empirical model } \\
\hline & $\begin{array}{r}\text { Model } 3 \\
\text { Table } 2\end{array}$ & $\begin{array}{r}\text { Model } 4 \\
\text { Table } 2\end{array}$ & $\begin{array}{r}\text { Model } 3 \\
\text { Table } 3\end{array}$ & $\begin{array}{r}\text { Model } 4 \\
\text { Table } 3\end{array}$ \\
\hline Number of positive and significant $t^{a}$ estimates & 17 & 17 & 17 & 17 \\
\hline Number of positive and insignificant estimates & 0 & 0 & 0 & 0 \\
\hline
\end{tabular}

Panel E: Coefficient estimates and $p$-values for $C R$ for regressions with country means

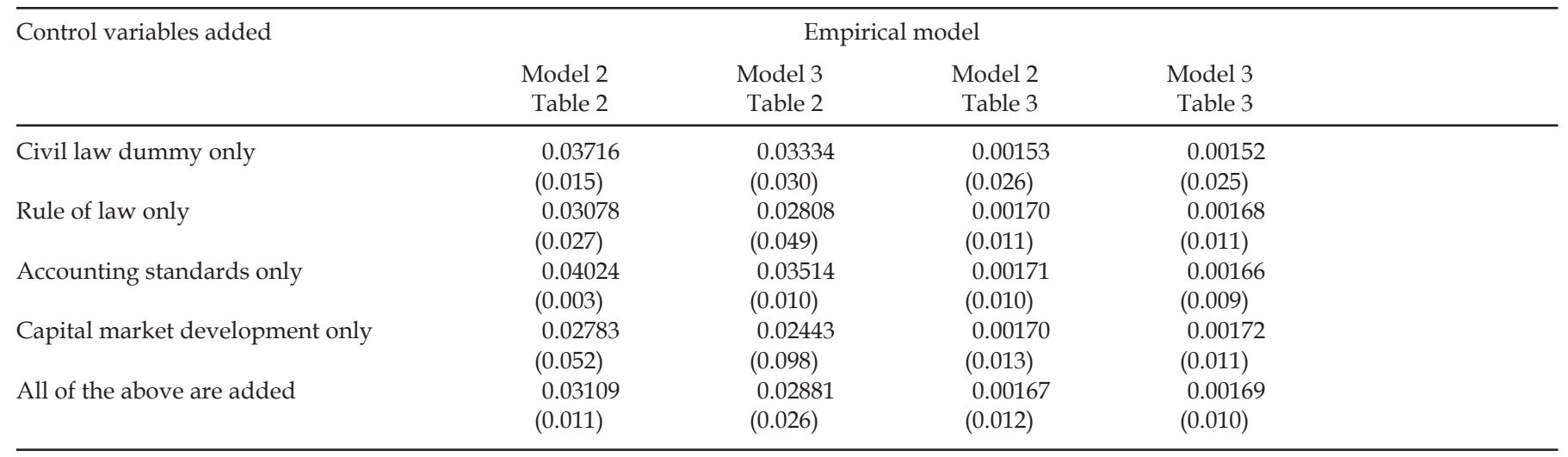

a At $10 \%$ level or less.

\subsubsection{Multivariate analyses using country means}

In this subsection, we use annual country-level means of the firm-specific variables in our regression equations. Using country-level averages has two advantages. First, it eliminates the disproportionate representation of countries like the US, UK, and Japan. This mitigates the possibility of our results being driven by a subset of countries, in addition to those identified on an ex ante basis in Panel C. Second, using country-level means also mitigates potential problems from within-country correlated residuals. For all regressions, we use an OLS framework and include year fixed effects with country-level clustered errors.

We report the country-level mean results in Panel E of Table 11. Similar to Panels A and B, we include various institutional features as additional controls. The CR coefficient estimates are positive and significant at the $10 \%$ level in all 20 regressions.

In summary, all of the robustness tests confirm our previous empirical results. Consistent with the substitute hypothesis, there is a positive and significant relation between creditor rights and dividend payouts.

\section{Conclusion}

The international governance literature to date has focused on conflicts of interest between controlling shareholders and minority shareholder interests. La Porta, Lopez-de-Silanes, Shleifer, and Vishny (2000), for example, show that strong shareholder rights reduce the agency costs of equity by enabling minority shareholders to secure high dividend payouts (i.e., the outcome hypothesis). In this study, we argue that country-level creditor rights influence dividend policies around the world by establishing the balance of power between debt and equity claimants. Creditors demand and managers consent to restrictive dividend payouts as a substitute for weak creditor rights since both parties have an incentive to minimize the agency costs of debt. Nini, Smith, and Sufi (2007) argue that creditors maintain control rights over corporate investment policies as a second-best solution to the agency costs of debt. Similarly, we find that creditors retain control rights over corporate payout policies as a solution to the agency costs of debt. Moreover, we show that the degree to which creditors retain control rights over payout policy depends significantly on country-level creditor rights.

Our empirical results are based on an international sample of 120,507 firm-year observations from 16,525 unique firms across 52 countries during the period 1990-2006. We examine the impact of creditor rights on the likelihood of paying dividends while controlling for firm maturity, leverage, profitability, sales growth, size, cash holdings, and shareholder rights. As hypothesized, we find a positive and significant relation between creditor rights and the probability of paying dividends. We examine the impact of creditor rights on dividend payout ratios and again find a positive and significant relation. Weak creditor rights lead to dividend restrictions, consistent with the substitute hypothesis. 
We also show that our empirical results are economically, as well as statistically, significant. A typical firm from the highest creditor rights environment is over $70 \%$ more likely to pay dividends than a typical firm from the lowest creditor rights environment. Similarly, as the creditor rights index increases from zero to four, the predicted payout ratio increases from $0.78 \%$ of firm sales to $1.98 \%$ of firm sales, a 2.5-fold increase in dividend payout ratios.

Next, we extend our analysis in several ways. First, we examine the explanatory power of the components of the creditor rights index. We find that most of the individual components exhibit the same positive relation with dividend payouts as the overall creditor rights index, both in terms of the propensity to pay as well as payout ratios. Second, we test and confirm that firms from weak creditor rights environments are more likely to omit a dividend than firms from strong creditor rights environments. Third, we show that firm-level credit quality reduces, but does not negate, the impact of creditor rights on dividend payouts. Fourth, we hypothesize and confirm that free cash flows intensify the positive relation between creditor rights and dividend payouts. Fifth, we test an alternative explanation for our empirical findings; namely, that the positive relation between creditor rights and dividend payouts is driven by poor access to external financing. We find no empirical support for this conjecture. Lastly, we run a series of robustness tests using additional control variables, time-variation in the independent variables, sample variations, Fama and MacBeth (1973) and country-mean regressions. All of these robustness tests confirm a positive and stable relation between creditor rights and dividend payout policies.

Overall, our study contributes to the corporate payout literature by proposing and confirming a substitute hypothesis based on agency costs of debt. We confirm that creditor rights play a significant role in determining dividend policies around the world. The weaker the country's creditor rights, the more likely it is that firms will restrict dividend payouts as a substitute bonding mechanism. Our results also contribute to the nascent literature on creditor control rights. Nini, Smith, and Sufi (2007) find that creditors exert control over corporate investment policies, and Roberts and Sufi (2007) find that creditors exert control over financing policies. Our results contribute to this growing body of research by showing that creditors exercise substantial control over dividend policies.

\section{References}

Bhattacharya et al., 2003 U. Bhattacharya, H. Daouk, and M. Welker, The world price of earnings opacity, The Accounting Review 78 (2003), pp. 641-678.

Brockman and Unlu, 2008 Brockman, P., Unlu, E., 2008. Earned/contributed capital, dividend policy, and disclosure quality: an international study. Working Paper, University of Missouri.

Citron, 1992 D. Citron, Accounting measurement rules in UK bank loan contracts, Accounting and Business Research 23 (1992), pp. 21-30.
Citron, 1995 D. Citron, The incidence of accountingbased covenants in UK public debt contracts: an empirical analysis, Accounting and Business Research 25 (1995), pp. 139-150.

Claessens et al., $2000>$ S. Claessens, S. Djankov, and L. Lang, The separation of ownership and control in East Asian corporations, Journal of Financial Economics 58 (2000), pp. 81-112.

Day and Taylor, 1996 J. Day and P. Taylor, Bankers perspectives on the role of covenants in debt contracts, Journal of International Banking Law May (1996), pp. 201-205.

DeAngelo and DeAngelo, 2006 H. DeAngelo and L. DeAngelo, The irrelevance of the MM dividend irrelevance theorem, Journal of Financial Economics 79 (2006), pp. 293-315.

DeAngelo et al., $2006 \rightarrow \mathrm{H}$. DeAngelo, L. DeAngelo, and R. Stulz, Dividend policy and the earned/contributed capital mix: a test of the life cycle theory, Journal of Financial Economics 81 (2006), pp. 227-254.

Demirguc-Kunt and Levine, 1996 A. Demirguc-Kunt and R. Levine, Stock market development and financial intermediaries: stylized facts, World Bank Economic Review 10 (1996), pp. 291-321.

Demirgüc-Kunt and Maksimovic, 1998 A. Demirgüc-Kunt and V. Maksimovic, Law, finance, and firm growth, Journal of Finance 53 (1998), pp. 2107-2137.

Denis and McConnell, 2003 D. Denis and J. McConnell, International corporate governance, Journal of Financial and Quantitative Analysis 38 (2003), pp. 1-36.

Denis and Osobov, $2008 \rightarrow$ D. Denis and I. Osobov, Why do firms pay dividends? International evidence on the determinants of dividend policy, Journal of Financial Economics 89 (2008), pp. 62-82.

Dittmar et al., 2003 A. Dittmar, J. Mahrt-Smith, and H. Servaes, International corporate governance and corporate cash holdings, Journal of Financial and Quantitative Analysis 38 (2003), pp. 111-133.

Djankov et al., 2006 S. Djankov, O. Hart, C. McLiesh, and A. Shleifer, Debt enforcement around the world. NBER Working Paper no. 12807 (2006).

Djankov et al., 2007 S. Djankov, C. McLiesh, and A. Shleifer, Private credit in 129 countries, Journal of Financial Economics 84 (2007), pp. 299-329.

Djankov et al., 2008 S. Djankov, R. La Porta, F. Lopez-de-Silanes, and A. Shleifer, The law and economics of self-dealing, Journal of Financial Economics 88 (2008), pp. 430-465.

Easterbrook, $1984 \longrightarrow$ F. Easterbrook, Two agency-cost explanations of dividends, American Economic Review 74 (1984), pp. 650-659.

Esty and Megginson, $2003-$ B. Esty and W. Megginson, Creditor rights, enforcement, and debt ownership structure, Journal of Financial and Quantitative Analysis 38 (2003), pp. 37-59.

Faccio et al., $2001>$ M. Faccio, L. Lang, and L. Young, Dividends and expropriation, American Economic Review 91 (2001), pp. 54-78.

Fama and French, 1998 E. Fama and K. French, Taxes, financing decisions, and firm value, Journal of Finance 53 (1998), pp. 819-843. 
Fama and MacBeth, $1973 \longrightarrow$ E. Fama and J. MacBeth, Risk, return, and equilibrium: empirical tests, Journal of Political Economy 81 (1973), pp. 607-636.

Grullon et al., 2005 G. Grullon, R. Michaely, S. Benartzi, and R. Thaler, Dividend changes do not signal changes in future profitability, Journal of Business 78 (2005), pp. 1659-1682.

Hanley and McNeil, 1982 J. Hanley and B. McNeil, The meaning and use of the area under a receiver operating characteristic (ROC) curve, Radiology 143 (1982), pp. 29-36.

Hope et al., 2004 O. Hope, T. Kang, and Y. Zang, The bonding hypothesis revisited: do cross-listing firms bond to the improved disclosure environment in the United States? Working Paper, University of Toronto (2004).

John and Nachman, 1985 K. John and C. Nachman, Risky debt, investment incentives, and reputation in a sequential equilibrium, Journal of Finance 40 (1985), pp. 863-878.

Johnson, $2003 \rightarrow$ S. Johnson, Debt maturity and the effects of growth opportunities, managerial discretion, and the security issue decision, Review of Financial Studies 16 (2003), pp. 209-236.

Johnson et al., $2000>$ S. Johnson, R. La Porta, F. Lopez-de-Silanes, and A. Shleifer, Tunneling, American Economic Review 90 (2000), pp. 22-27.

Kalay, 1982 A. Kalay, Stockholder-bondholder conflict and dividend constraints, Journal of Financial Economics $\mathbf{1 0}$ (1982), pp. 211-233.

Kaufmann et al., 2003 D. Kaufmann, A. Kraay, and M. Mastruzzi, Governance matters III: governance indicators for 1996-2002. World Bank Policy Research Working Paper no. 3106 (2003).

Khurana et al., 2006 I. Khurana, X. Martin, and R. Pereira, Financial development and the cash flow sensitivity of cash, Journal of Financial and Quantitative Analysis 41 (2006), pp. 787-807.

La Porta et al., $1997 \rightarrow$ R. La Porta, F. Lopez-de-Silanes, A. Shleifer, and R. Vishny, Legal determinants of external finance, Journal of Finance 52 (1997), pp. 1131-1150.

La Porta et al., $1998 \rightarrow$ R. La Porta, F. Lopez-de-Silanes, A. Shleifer, and R. Vishny, Law and finance, Journal of Political Economy 106 (1998), pp. 1113-1155.

La Porta et al., $1999>$ R. La Porta, F. Lopez-de-Silanes, A. Shleifer, and R. Vishny, The quality of government, Journal of Law, Economics, and Organization 15 (1999), pp. 222-279.

La Porta et al., $2000>$ R. La Porta, F. Lopez-de-Silanes, A. Shleifer, and R. Vishny, Agency problems and dividend policies around the world, Journal of Finance 55 (2000), pp. 1-33.

La Porta et al., $2002>$ R. La Porta, F. Lopez-de-Silanes, A. Shleifer, and R. Vishny, Investor protection and corporate valuation, Journal of Finance 57 (2002), pp. 1147-1170.

La Porta et al., 2006 R. La Porta, F. Lopez-de-Silanes, and A. Shleifer, What works in securities laws?, Journal of Finance 61 (2006), pp. 1-32.

Leuz et al., 1998 C. Leuz, D. Deller, and M. Stubenrath, An international comparison of accounting-based payout restrictions in the United States, United Kingdom and Germany, Accounting and Business Research 28 (1998), pp. 111-129.
Leuz et al., 2003 C. Leuz, D. Nanda, and P. Wysocki, Earnings management and investor protection: an international comparison, Journal of Financial Economics 69 (2003), pp. 505-527.

Long et al., 1994 M. Long, I. Malitz, and S. Sefcik, An empirical examination of dividend policy following debt issues, Journal of Financial and Quantitative Analysis 29 (1994), pp. 131-144.

Love, 2003 I. Love, Financial development and financing constraints: International evidence from the structural investment model, Review of Financial Studies 16 (2003), pp. 765-791.

Malitz, 1986 I. Malitz, On financial contracting: the determinants of bond covenants, Financial Management (Summer 1986), pp. 18-25.

Mather and Peirson, 2006 P. Mather and G. Peirson, Financial covenants in the markets for public and private debt, Accounting and Finance 46 (2006), pp. 285-307.

Morck et al., $2000>$ R. Morck, B. Yeung, and W. Yu, The information content of stock markets: why do emerging markets have synchronous price movements?, Journal of Financial Economics 58 (2000), pp. 215-260.

Nini et al., 2007 G. Nini, D. Smith, and A. Sufi, Creditor control rights and firm investment policy. Journal of Financial Economics, forthcoming (2007).

Niskanen and Niskanen, 2004 J. Niskanen and M. Niskanen, Covenants and small business lending: the Finnish case, Small Business Economics 23 (2004), pp. 137-149.

Petersen, 2006 M. Petersen, Estimating standard errors in finance panel data sets: comparing approaches. Northwestern University Working Paper no. 329 (2006).

Pinkowitz et al., $2003 \rightarrow$ L. Pinkowitz, R. Stulz, and R. Williamson, Do firms in countries with poor protection of investor rights hold more cash? NBER Working Paper no. 10188 (2003).

Rajan and Zingales, 1998 R. Rajan and L. Zingales, Financial dependence and growth, American Economic Review 88 (1998), pp. 559-586.

Roberts and Sufi, $2007 \rightarrow$ M. Roberts and A. Sufi, Control rights and capital structure: An empirical investigation. Working Paper, University of Chicago (2007).

Smith and Warner, 1979 C. Smith and J. Warner, On financial contracting: an analysis of bond covenants, Journal of Financial Economics 7 (1979), pp. 117-161.

Thornton, $1992>$ D. Thornton, Cost of accounting to lenders: Canadian evidence, Accounting and Business Research 22 (1992), pp. 261-273.

Whittred and Zimmer, 1986 G. Whittred and I. Zimmer, Accounting information in the market for debt, Accounting and Finance 26 (1986), pp. 19-33.

Wurgler, 2000 J. Wurgler, Financial markets and the allocation of capital, Journal of Financial Economics 58 (2000), pp. 187-214. 